\title{
Episodic post-rift deformation in the south-eastern Australian passive margin: evidence from the Lapstone Structural Complex
}

\author{
Andrew McPherson, ${ }^{1 *}$ Dan Clark, ${ }^{1}$ Mike Macphail $^{2}$ and Matthew Cupper $^{3}$ \\ ${ }^{1}$ Geoscience Australia, GPO Box 378, Canberra, ACT, 2601, Australia \\ ${ }^{2}$ Consultant Palynological Services, 13 Walu Place, Aranda, ACT, 2614, Australia \\ ${ }^{3}$ School of Earth Sciences, The University of Melbourne, Melbourne, Victoria, 3010, Australia
}

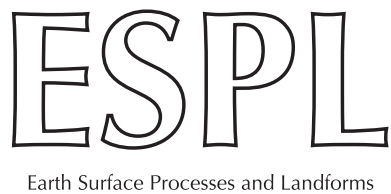

ABSTRACT: Identifying the influence of neotectonics on the morphology of elevated passive margins is complicated in that major morpho-structural patterns might plausibly be explained by processes related to late Mesozoic to early Cenozoic rifting and/or differential erosion induced by Cenozoic epeirogenic uplift. The proportional contribution of each process can vary from continent to continent, and potentially even within the same passive margin.

In the passive margin setting of the southeast Australian highlands the documented occurrence of neotectonic deformation is rare, and accordingly its role in landscape evolution is difficult to establish. The results of investigations within the Lapstone Structural Complex, which forms the eastern range front of the Blue Mountains Plateau, provide evidence for two periods of Cenozoic neotectonic uplift in this part of the highlands. The first, demonstrated by seismic and structural evidence, is suggested to have occurred in the Paleogene, and is thus unrelated to Cretaceous rifting. The second period, demonstrated by evidence from the Kurrajong Fault (presented herein) suggests that uplift occurred in both the Mio-Pliocene and the Middle Pleistocene. The cumulative Neogene and younger uplift of $\sim 15 \mathrm{~m}$ determined for the Kurrajong Fault is less than $10 \%$ of the $130 \mathrm{~m}$ of total measured throw across the fault. The apparently minor contribution of neotectonism to the current elevation of the Blue Mountains Plateau supports a predominantly erosional exhumation origin for the topographic relief at the plateau's eastern edge. This finding contrasts with evidence from fault complexes associated with similar topographic relief elsewhere in the south-eastern highlands, indicating that present-day topography cannot be directly related to relief generated by Neogene and younger uplift, even from relatively closely-spaced $(<150 \mathrm{~km})$ structures within the same passive margin. These findings have implications for understanding the spatio-temporal variability of post-rift faulting in continental passive margin settings and the evolution of landscapes therein. (c) Commonwealth of Australia. Earth Surface Processes and Landforms (c) 2014 John Wiley \& Sons, Ltd.

KEYWORDS: neotectonic; south-eastern highlands; Neogene; passive margin; Lapstone Structural Complex

\section{Introduction}

Low-relief, large-scale, dissected plateaux separated from an adjacent coastal plain by a pronounced escarpment are a common feature of the Earths' elevated passive margins, examples of which include southern Africa, eastern Brazil, western India, the northern North Atlantic and eastern Australia (e.g. Japsen et al., 2009, and references cited therein). Despite their global distribution, the geomorphic and structural evolution of many elevated passive continental margins remains the subject of debate. Specifically, the timing of uplift to their present elevation, and the relationship of the uplift to rift- or non-rift-related structures is often cryptic. Have they been permanently uplifted since the time of rifting (typically Cretaceous), or does uplift pertain to Cenozoic events unrelated to rifting? Apatite fission track thermochronology (AFTT) and geomorphic evidence from West Greenland (Japsen et al., 2006, 2009), Scandinavia (Bonow et al., 2006) and Africa (Gallagher and Brown, 1999a, 1999b) indicates that the majority of the present relief generation along the margins studied post-dates rifting. The similarity of these margins to other passive margins worldwide led Japsen et al. (2009) to question whether episodic post-rift uplift unrelated to the process of rifting and continental separation might be more common than is generally assumed.

The south-east Australian Highlands and the Kosciuszko uplift

The south-eastern highlands of the eastern Australian passive margin are characterized by some of the greatest relief on the continent, and some of the highest bedrock erosion rates - in the order of 20 to $50 \mathrm{~m} / \mathrm{Ma}$ (e.g. Bishop, 1985; Bishop et al., 1985; Weissel and Seidl, 1998; Bishop and Goldrick, 2000; Heimsath et al., 2000, 2001; Wilkinson et al., 2005; Tomkins et al., 2007; Heimsath et al., 2010). Contemporary relief in 
the region is hypothesized to have resulted from a variety of mechanisms, including flexural unloading of the rift flank during extension (e.g. Weissel and Karner, 1989), base-level change initiated at a rift margin (e.g. van der Beek et al., 1999), lithospheric shortening (e.g. Braun et al., 2009) and dynamic topography related to northward plate motion over a pre-existing pattern of mantle convective circulation (e.g. Heine et al., 2010; Czarnota et al., 2013, 2014). Proposed timings for the uplift that drove relief development vary from Late Paleozoic through to Miocene (see Vandenberg, 2010). AFTT data appear to constrain the earliest possible timing to the Late Mesozoic (e.g. Kohn et al., 1999; O'Sullivan et al., 1999), temporally coincident with the rift-related opening of the Tasman Sea (Norvick and Smith, 2001).

Holdgate et al. (2008) present evidence from the Victorian part of the south-eastern highlands (see Figure 1) which resurrected the idea of a more recent punctuated uplift 'event' - the post-Eocene Kosciuszko Uplift (Andrews, 1910; Sprigg, 1945; Browne, 1967) - that continued into the Late Pliocene and potentially into the Pleistocene. The applicability of this thesis to the broader south-eastern highlands is subject to debate (e.g. Brown, 2008; Holdgate et al., 2008; Vandenberg, 2010; Holdgate et al., 2011; Norvick, 2011). It is plausible that this postulated Cenozoic uplift might be responsible for adding several hundred metres of relief to the highlands. The Neogene and younger components of any such uplift may even relate to the pulse of deformation seen in southeast Australian offshore basins between c. 10-5 Ma (Dickinson et al., 2001, 2002), associated with the reorganization of the crustal stress field into its present configuration commencing in the Late Miocene (Sandiford et al., 2004; Hillis et al., 2008; Holford et al., 2012).

An epeirogenic mechanism for this punctuated and longlived uplift is not readily apparent, nor have any crustal fault systems which might have accommodated such a large-scale uplift been identified. However, perturbations in age distributions derived from AFTT data for south-eastern Australia suggest a dominant fault-related mechanism underpinning uplift (Braun et al., 2009).

Holdgate et al. (2006) and Vandenberg (2010) report faults demonstrating late Cenozoic displacement in the Victorian part of the south-eastern highlands, while a handful of fault systems with structural relief on the order of hundreds of metres or more

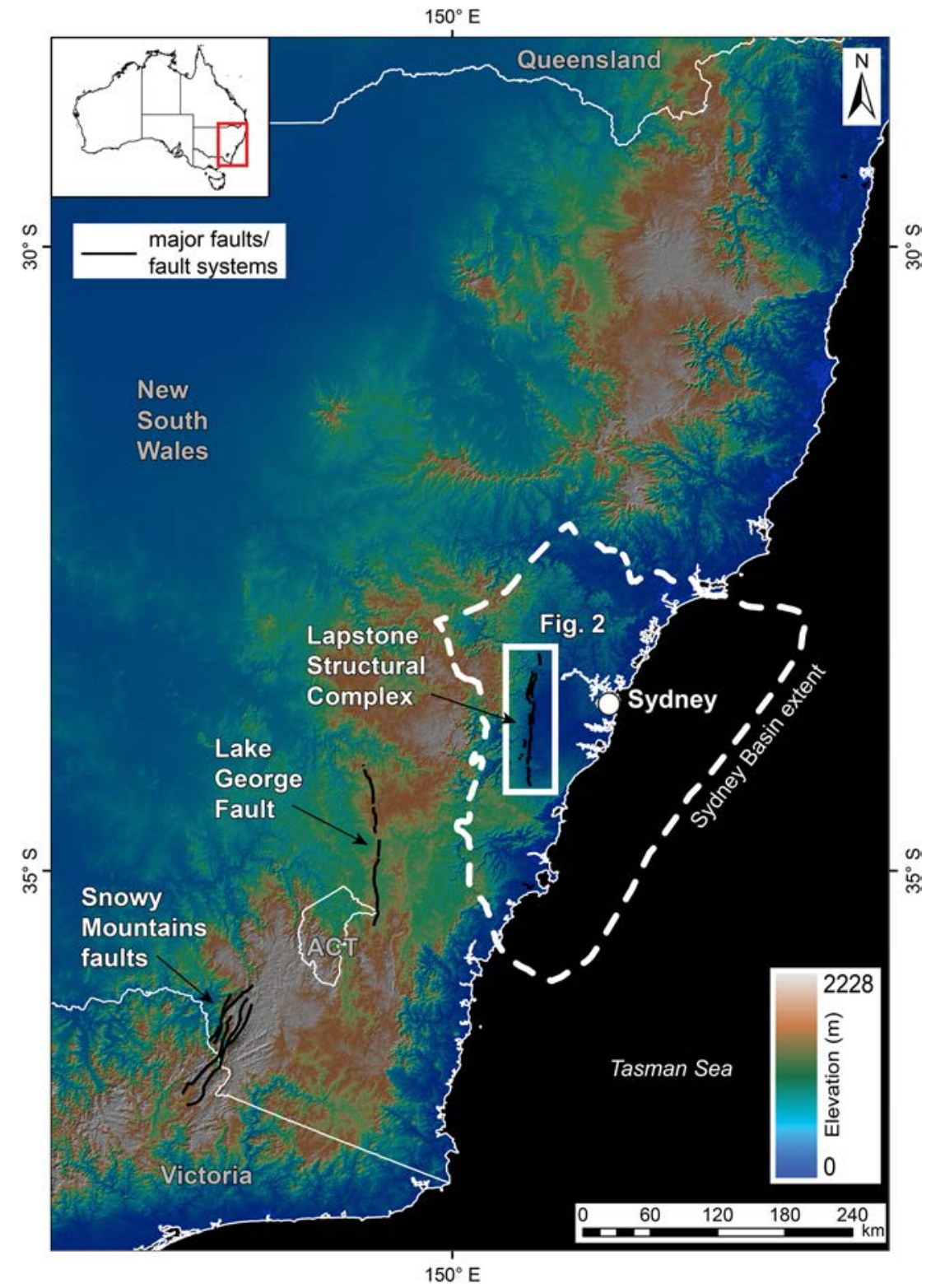

Figure 1. Digital elevation model [Shuttle Radar Topography Mission (SRTM): $90 \mathrm{~m}$ ) showing the Eastern Highlands of south-eastern Australia, which reach a maximum elevation of $2228 \mathrm{~m}$ above sea-level. Fault structures or complexes mentioned in text are shown, as is the outline of the Permo-Triassic Sydney Basin. 
are also documented (e.g. Webb et al., 2011). Examples such as the Tawonga and Kiewa Faults (Beavis, 1960, 1962; Beavis and Beavis, 1976; Orr, 1999), the Khancoban-Yellow Bog Fault (Moye et al., 1963; Sharp, 2004) and the Berridale Fault (Lambert and White, 1965) are located in the Snowy Mountains region of southern New South Wales/northeast Victoria (Figure 1). Further to the north along the continental divide, evidence from the Lake George Fault suggests that some topography relating to that structure already existed before the Neogene (Young and Bishop, 1980; Young, 1981), although $70 \%$ of the known displacement on the fault is considered to be Neogene or younger (Coventry, 1976; Singh et al., 1981; Abell, 1985, 1991). The sedimentary history of the Lake George Basin currently provides no evidence to suggest that it has experienced any tectonic deformation since the Late Pleistocene (Coventry, 1976), and that since that time sedimentation rates have been more strongly controlled by climate, particularly during the Holocene (Fitzsimmons and Barrows, 2010).

The focus of this paper is the Lapstone Structural Complex (LSC), west of Sydney, New South Wales (Figure 1). The LSC is associated with up to $400 \mathrm{~m}$ of structural and topographic relief, and considerable debate exists as to the timing of relief generation, and its relationship to rifting. We present the results of an investigation of sediments infilling Mountain Lagoon - a small basin bounded by the Kurrajong Fault, in the central LSC. This basin archives a history of Neogene and younger tectonic activity on the Kurrajong Fault. As a result of the structural relationships within the LSC, displacements on the fault can be used as a proxy for neotectonic activity on the LSC as a whole. Comparison of results from the LSC against data for known structures elsewhere in the south-eastern highlands provides insights into variation in the timing and magnitude of neotectonic deformation in the region and the relative influence of tectonism on landscape evolution.

\section{Lapstone Structural Complex (LSC)}

The LSC consists of a series of approximately north-south trending faults and monoclinal flexures, including the prominent Lapstone Monocline (Figure 2), that underlie the eastern

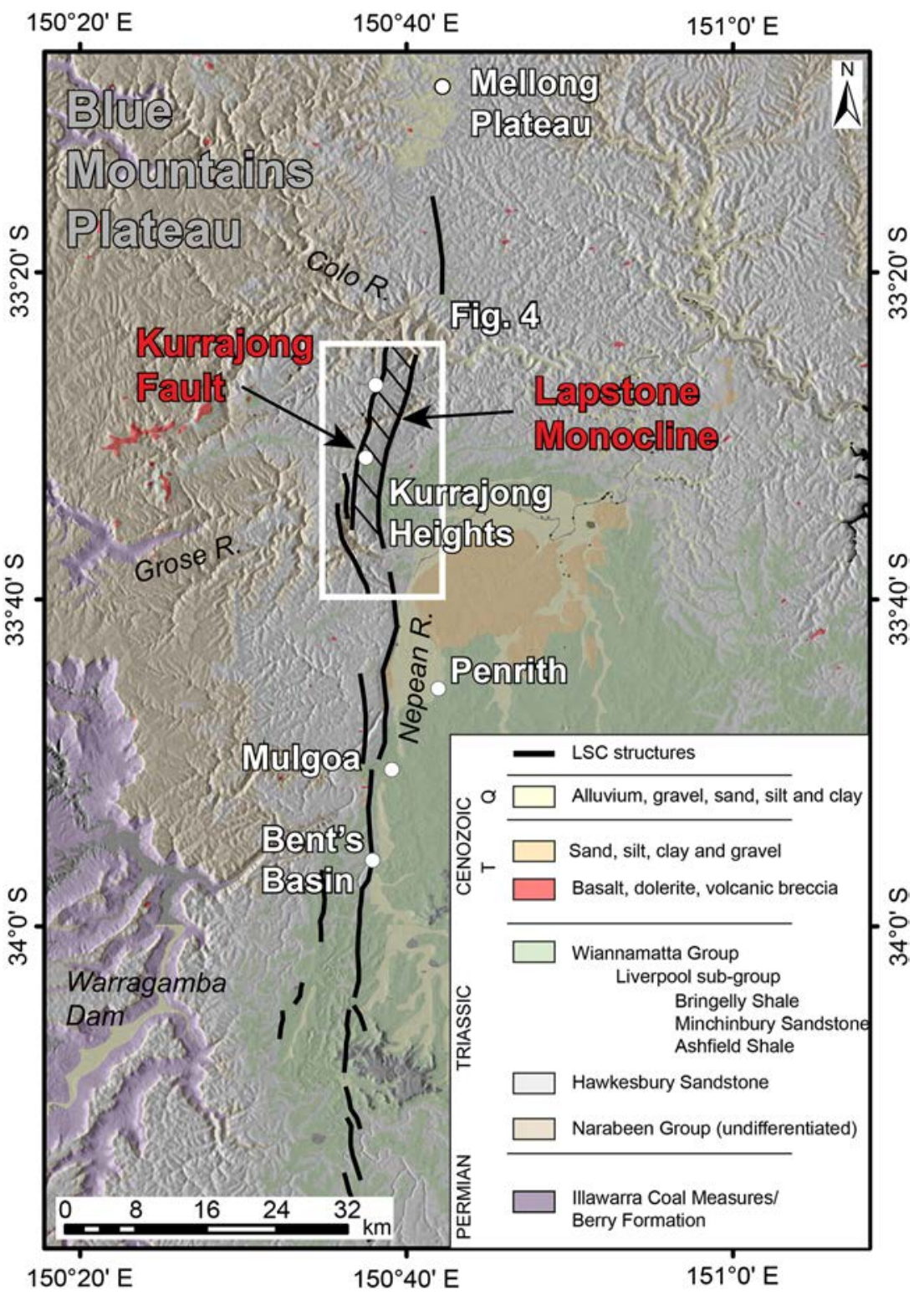

Figure 2. Digital elevation model (SRTM: $90 \mathrm{~m}$ ) of the Lapstone Structural Complex (LSC), $60 \mathrm{~km}$ west of Sydney, NSW. Solid black lines denote major structures of the LSC; broad hatching identifies the approximate extent of the Lapstone Monocline (after Branagan and Pedram, 1990). Geology derived from the Sydney (Bryan, 1966) and Wollongong (Rose, 1966) 1:250 000 geological sheets superimposed over hill-shaded relief. Localities and major streams mentioned in text are labelled. 
range front of the Blue Mountains plateau over a distance of as much as $160 \mathrm{~km}$ (Mauger et al., 1984; Branagan and Pedram, 1990; Pickett and Bishop, 1992) (Figures 1 and 2). The topography of the eastern range front is strongly controlled by structural relief across the erosionally-resistant Hawkesbury Sandstone (Herbert and Helby, 1980; Pickett and Bishop, 1992). This geological unit, along with the Ashfield Shale (Herbert, 1979), dominate the surface geology of the study area. Both units are locally disconformably overlain by post-Triassic strata (Figure 2), amongst which those of most relevance to the present study are Miocene alkali olivine basalts dated at 14-20 Ma (Wellman and McDougall, 1974; van der Beek et al., 2001), and Cenozoic alluvial deposits. The basalts generally occur to the west of the LSC as remnants of larger flows that were erupted onto a relatively subdued, low-relief land-surface (van der Beek et al., 2001), while alluvial deposits are common to the east of the base of the Lapstone Monocline (Figure 2), e.g. the Rickabys Creek Gravel (Gobert, 1978; Chesnut, 1982; Bishop and Hunter, 1990; Pickett and Bishop, 1992). These gravels are found both on the face, and to the east, of the Lapstone Monocline, and are interpreted by Nanson and Young (1987) to be conglomerates deposited by a braided stream (the palaeo-Wollondilly River system). The age of these deposits is not known.

The LSC can be broadly divided into three domains on the basis of structural, geomorphic and topographic characteristics (Figure 3; refer to Figure 2 for locations). South of the village of Mulgoa the range front is sharp and linear for almost $55 \mathrm{~km}$. Seismic reflection data indicate that the escarpment is underlain by the steeply west-dipping $\left(60^{\circ}-80^{\circ}\right)$ Nepean Fault System (Herbert, 1989; Bray et al., 2010; Fergusson et al., 2011). Triassic Hawkesbury Sandstone and Ashfield Shale (Herbert, 1979) are folded into a prominent hanging wall anticline at Bents Basin (maximum $85^{\circ}$ east dip), and abut almost horizontal strata immediately east of the fault (Branagan and Pedram, 1990; Fergusson et al., 2011). Several shorter, eastfacing fault scarps relating to structures imaged in seismic reflection data occur a few kilometres to the west of the main range front (Bray et al., 2010). It is not known whether these faults maintain a steep dip below the couple of kilometres depth captured by seismic imaging. Structural relief is in the order of 50-100 m (Figure 3).
In the central domain, from Mulgoa northwards to the Colo River, the range front is underlain by a series of west-dipping faults (Branagan and Pedram, 1990; Fergusson et al., 2011) and east-facing monoclines, most notably the Lapstone Monocline (Figure 2). Two to three kilometres to the west of the range front and parallel to it, a series of en echelon faults are associated with west-facing fault scarps - the Glenbrook, Yellow Rock, Frasers, Blue Gum, Grose, Burralow and Kurrajong Faults (Branagan and Pedram, 1990) (Figure 4). For ease of reference, these faults are herein collectively termed the Kurrajong Fault System (KFS), after Pedram (1983). Faults of the KFS are interpreted to coalesce at depth (Herbert, 1989; Clark and Rawson, 2009). Relief across this section of the LSC increases from south to north, reaching a maximum of $400 \mathrm{~m}$ near the Colo River (Figure 3).

Many of the west-facing scarps in this region are associated with swamps and small lakes, such as Mountain Lagoon, Burralow Swamp, Blue Gum Swamp, Shaw's Creek Swamp and Warrimoo Swamp (Rawson, 1990; Rawson and Clark, 2009). Rawson (1990) investigated the depth of sedimentary fill in several of these basins and found that most contained less than $5 \mathrm{~m}$ of unconsolidated sediment. The exceptions are Burralow Swamp ( 20 m - Rawson, 1990) and Mountain Lagoon ( 23 $\mathrm{m}$ - this study) (Figure 4). This was taken as an indication that long-term average incision rates into the fault barriers closely match the long-term average uplift rates of the fault barriers (Rawson and Clark, 2009). A series of drill-holes in Burralow Swamp identified a 6-7 m thick buried clay lens which was interpreted to relate to fault damming of Burralow Creek at some time during the Late Pleistocene (Rawson, 1990; Rawson and Clark, 2009). Episodic uplift on the Burralow Fault is implied (Clark et al., 2012).

North of the Colo River, the topographic character of the eastern range front of the Blue Mountains becomes subdued (Figure 3). Relief across the range front varies from 100 to $300 \mathrm{~m}$. No faults have been mapped as underlying the range front north of the Colo River. However, the topography is consistent with the existence of a broad east-facing monocline (Galloway, 1967; Henry, 1987), punctuated locally by short, discrete fault traces. Over a distance of 30 to $40 \mathrm{~km}$ drainage is transverse - flowing westerly against the general gradient of the topography through the northern part of the LSC. The upper

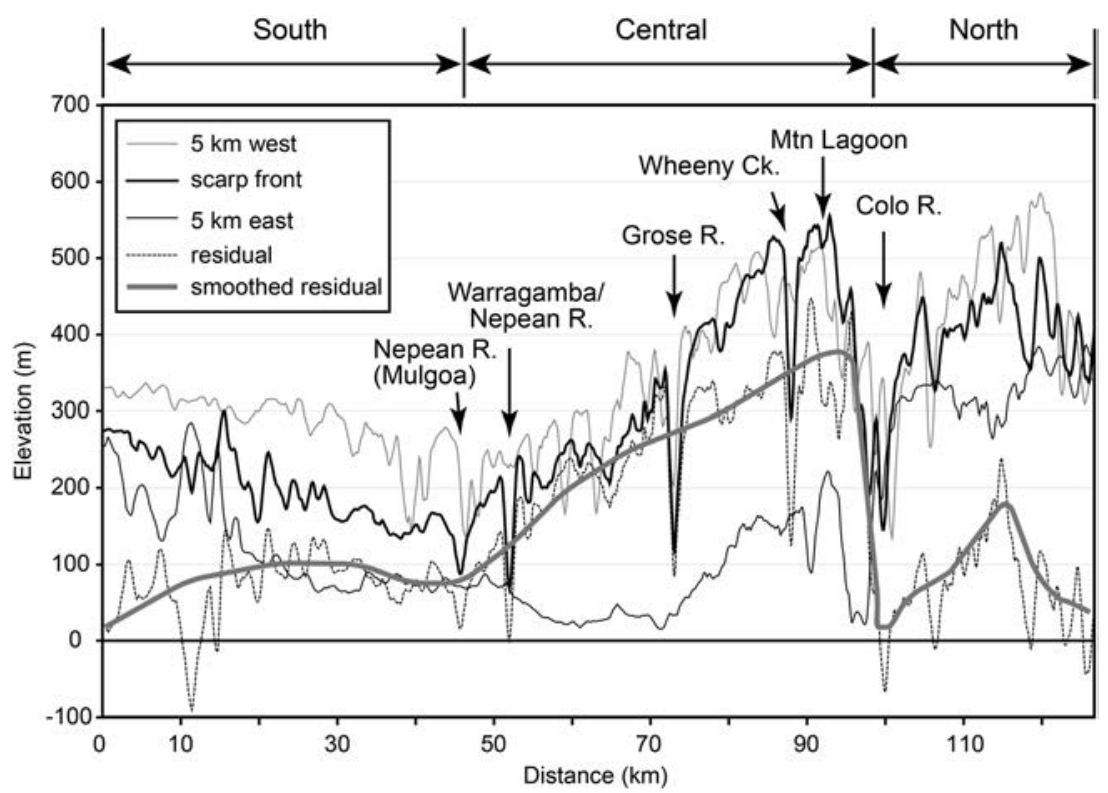

Figure 3. Scarp-parallel topographic profiles running north to south along the LSC (from Clark and Rawson, 2009). Refer to Figure 2 for locations. Residual (black dotted line) represents the difference in elevation between the top of the scarp and $5 \mathrm{~km}$ east of the scarp front. Residual line is depressed south of the Nepean River as some deformation is accommodated on structures to the west of the main range front. 


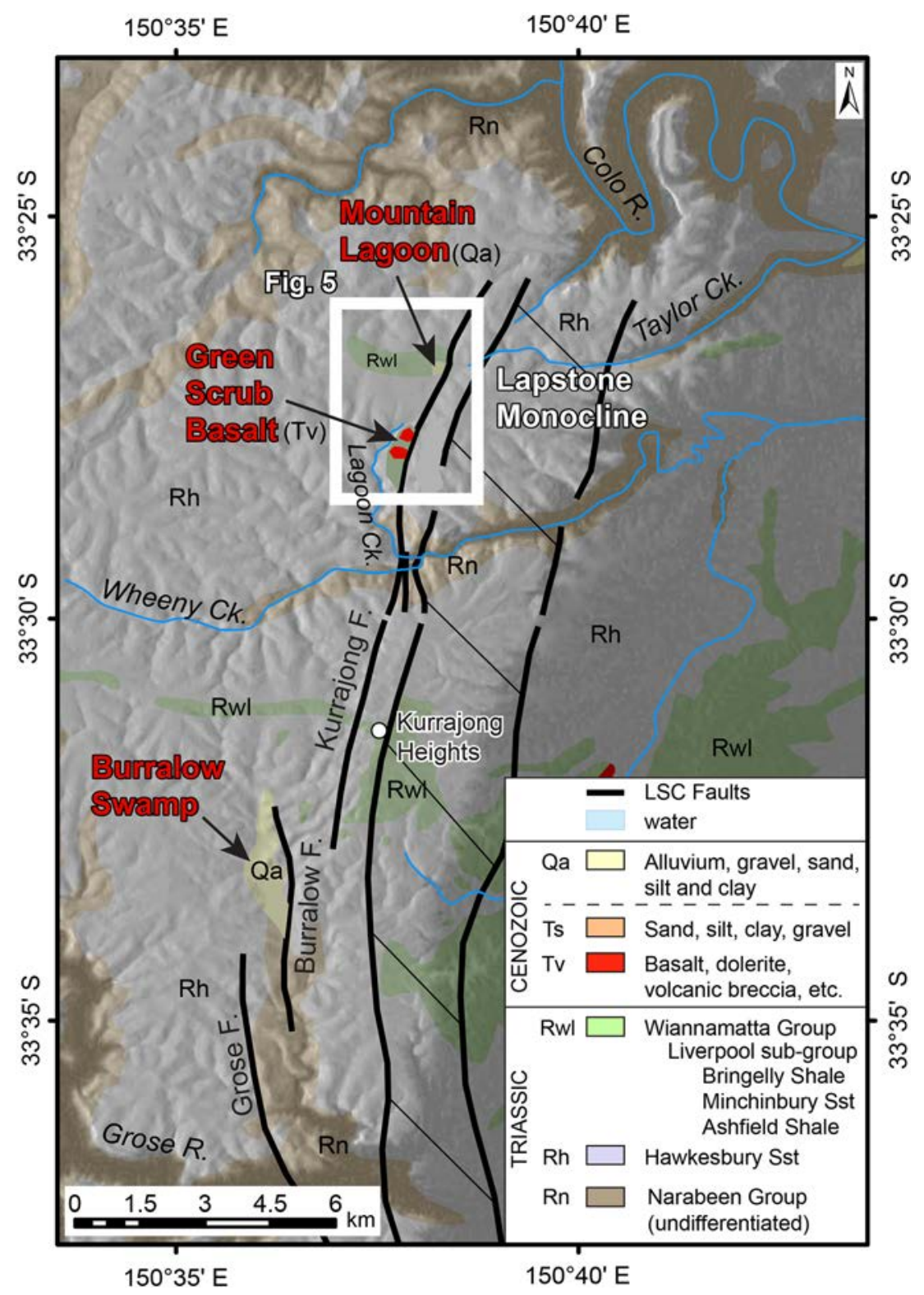

Figure 4. Digital elevation model (NSW Department of Land and Property Information: $25 \mathrm{~m}$ ) of the central Lapstone Structural Complex (LSC). The Grose, Burralow and Kurrajong Faults form part of the Kurrajong Fault System (KFS); broad hatching identifies the approximate extent of the Lapstone Monocline (after Branagan and Pedram, 1990). Geology derived from the Sydney 1:250 000 geological sheet (Bryan, 1966) superimposed over hill-shaded relief. Locations and major streams mentioned in text are marked. Features of note include (i) Mountain Lagoon, which is underlain by remnant Triassic Ashfield Shale, (ii) the Green Scrub Basalt, which sits elevated relative to the lagoon and just to its south, and (iii) Burralow Swamp - another confined drainage apparently trapped upstream of a known fault.

reaches of streams in this area, known as the Mellong Plateau (Figure 2), are extensively alluviated and large swamps occur on major creeks and tributaries. Valley infill beneath the swamps is typically less than $10 \mathrm{~m}$ thick (Henry, 1987; Riley and Henry, 1987). One of several possible explanations for swamp formation involves the back-rotation of stream channels resulting from vertical growth (displacement) on a northern extension of the Lapstone Monocline (Galloway, 1967; Henry, 1987). The age of valley fill sediments is poorly constrained. Black et al. (2007) obtained a radiocarbon age from a sediment core in Kings Waterhole (Howes Swamp) of 6014-6491 cal. years BP ( $\beta$-186148) at a depth of $5.5 \mathrm{~m}$. It was not reported whether bedrock was intersected at the bottom of the hole. Henry (1987) reports Quaternary pollen at $3.5 \mathrm{~m}$ depth from an embayment near Culloul Creek. Samples from deeper in Henry's borehole sections were too oxidized to yield datable pollen assemblages.
Deformation History of the LSC

A variety of ages have been proposed for the development of the structural and topographic relief relating to the LSC, and in particular the Lapstone Monocline. Alternative views propose that fold development was largely complete by the Early Jurassic (Pickett and Bishop, 1992), the Late Jurassic (Herbert, 1989), the Early Tertiary (Branagan and Pedram, 1990; van der Beek and Braun, 1999), and the Late Tertiary (Bishop et al., 1982, with age recalculated by Pillans, 2003). Relief generation has been associated with erosional exhumation of structures produced by Late Mesozoic to Early Cenozoic deformation (Bishop et al., 1982; Qureshi, 1984; Leaman, 1990; Pickett and Bishop, 1992; Schmidt et al., 1995; van der Beek et al., 2001) and with post-mid Miocene tectonism (David, 1902; Wellman, 1987; IGNS, 1999).

The idea that basement structures that were active during deposition of the Sydney Basin sediments in the Late Paleozoic 
to Early Mesozoic have played a significant role in the development of the LSC (Qureshi, 1984; Harrington and Korsch, 1985; Branagan and Pedram, 1990; Pickett and Bishop, 1992) is contentious. For example, seismic and structural evidence suggest dominantly Paleogene uplift under a compressional stress regime (Bray et al., 2010; Fergusson et al., 2011). This same compressional setting, which continues to the present day (Dyksterhuis and Müller, 2008; Hillis et al., 2008), is also considered to have influenced the Early Neogene cessation of basaltic volcanism in this part of eastern Australia (Wellman and McDougall, 1974).

Several other lines of evidence support a Cenozoic age for a significant portion of the relief generated across the LSC. These include (a) the eruption of Miocene basalts onto a low-relief pre-incision land-surface west of the LSC (Wellman and McDougall, 1974; van der Beek et al., 2001), and (b) the occurrence of deeply weathered (and occasionally indurated) Late Mesozoic to Early Tertiary (David, 1896) or Miocene (Gobert, 1978) Rickabys Creek Gravel. The latter shows an internal structure consistent with deposition in a braided stream environment (Chesnut, 1982; Nanson and Young, 1987; Bishop and Hunter, 1990), on both uplifted and downthrown sides of the Lapstone Monocline (Bishop, 1986; Branagan and Pedram, 1990).

Apparent truncation of the 18.8 Ma Green Scrub Basalt by the Kurrajong Fault (Grady and Hogbin, 1926; Crook, 1956; Pedram, 1983; Branagan and Pedram, 1990) (Figure 4) has been cited as evidence for Cenozoic deformation. However, at present the reported evidence is inconclusive in determining whether the basalt has actually been faulted (cf. Branagan and Pedram, 1990), or whether a fault scarp that existed prior to the eruption of the basalt simply contained the basalt flow.

Unconformable deposition of the Rickabys Creek Gravel (Gobert, 1978) over Hawkesbury Sandstone on the face and up-thrown side of the Lapstone Monocline, and over Ashfield Shale on the downthrown side has been used to argue for erosional exhumation of a pre-Jurassic structure (Pickett and Bishop, 1992). However, palaeomagnetic data show that rotation of strata on the limb of the Lapstone Monocline occurred after the mid-Cretaceous ( 90 Ma) (Schmidt et al., 1995) and before $8 \pm 5 \mathrm{Ma}$ (i.e. Late Miocene - Bishop et al., 1982, with ages recalculated by Pillans, 2003). Combined with evidence for Paleogene uplift (Bray et al., 2010; Fergusson et al., 2011), the implication is that development of the Lapstone Monocline is potentially asynchronous with Tasman Sea rifting (cf. Branagan, 1975; Schmidt et al., 1995), and that much of the uplift on the LSC had taken place by the Late Neogene. Notwithstanding this, Rawson (1990) and Rawson and Clark (2009) present evidence to suggest that some Miocene and younger deformation has taken place on LSC structures. This includes the observation that a number of east-flowing drainage lines have been captured or impeded, potentially by faulting.

\section{Mountain Lagoon}

Mountain Lagoon is located immediately west of the Kurrajong Fault scarp in the central LSC, on an interfluve between streams draining north and east into the Colo River (Figures 4 and 5). The 'lagoon' is a small, effectively closed basin which captures east-flowing drainage from a catchment covering an area of less than $5 \mathrm{~km}^{2}$ and has no clearly defined natural inflowing or outlet channels (Figure 5a). The catchment is characterized by a thin veneer of remnant Ashfield Shale (Figure 4), overlying Hawkesbury Sandstone (Grady and Hogbin, 1926). Shale has been removed by erosion on the up-thrown eastern side of the Kurrajong Fault. At Kurrajong Heights, $10 \mathrm{~km}$ to the south of Mountain Lagoon (Figure 4), the shale/sandstone contact is reported to be vertically displaced across the Kurrajong Fault by $130 \mathrm{~m}$ (David, 1902; Grady and Hogbin, 1926; Pedram, 1983; Branagan and Pedram, 1990).

The present-day 'lagoon' is connected to Lagoon Creek by an artificial drainage channel on its southern side (Figure 5a). This channel was established in the early twentieth century to drain the lagoon for cultivation purposes (Grady and Hogbin, 1926). While there is no visible evidence of natural surface drainage, the shape of the basin's southern margin does not preclude such a feature existing below ground level. Similarly, a V-notch profile cut through the wind gap to the east (Figure 5b) is evidence that a channel once connected Mountain Lagoon to Taylor Creek, an ephemeral stream that now drains the area to the east of the Kurrajong Fault into the Colo River (Figure 5a). A series of colluvial slopes prograde westward from the Kurrajong Fault scarp into the 'Iagoon'. The eastern shoreline is separated from Taylor Creek by a very low relief $(<5 \mathrm{~m})$, broad convex ridge which slopes gently $(<3 \%)$ to the east and west, with elevation decreasing from south to north. Rather than a colluvial deposit, the ridge appears to be an alluvial fan debouching from Russell Creek - a small northwest-draining gully originating on the up-thrown eastern side of the Kurrajong Fault scarp (Figure 5a). This gully has been captured by the headwaters of Taylor Creek.

The c. 18.8 Ma Green Scrub Basalt (Wellman and McDougall, 1974) occurs on the scarp face approximately $1.5 \mathrm{~km}$ south of Mountain Lagoon (Figure 5a). The deposit is interpreted to be a flow which formed part of an extensive province of Miocene alkali olivine basalts dated at 14-20 Ma (Grady and Hogbin, 1926; Crook, 1956; Adamson, 1962; Wellman and McDougall, 1974; van der Beek et al., 2001). These rocks are considered to have mantled a generally low-relief land surface that predates the migration of knickpoints up the major streams to form the current dissected, high-relief landscape (van der Beek and Braun, 1999; van der Beek et al., 2001).

\section{Investigations at Mountain Lagoon}

\section{Geophysical characterization of the buried Kurrajong Fault}

An electrical resistivity survey was conducted on the eastern margin of the lagoon to test the hypothesis that the Mountain Lagoon basin formed and was maintained as the result of uplift on the Kurrajong Fault. The survey aimed to identify the location of the buried fault and determine the depth and distribution of resistant Hawkesbury Sandstone bedrock on the up-thrown side.

Data was collected along a series of approximately eastwest oriented transects up to $100 \mathrm{~m}$ long (Figure 6) using a multi-electrode system comprising stainless steel spikes at $2 \mathrm{~m}$ intervals (Advanced Geosciences Inc. Supersting R1, Austin, TX). The system was configured in a Wenner array (Griffiths and Turnbull, 1985; Griffiths et al., 1990) and the resistivity data was modelled using AGI's Earthimager software to produce resistivity-depth sections.

Figure 7a presents the modelled resistivity at a depth of $20 \mathrm{~m}$ below ground surface. This highlights a prominent northtrending linear boundary (denoted by red arrows) between resistive material to the east (pink, red and orange), and relatively less resistive materials to the west (blue and green). This boundary is parallel to the Kurrajong Fault escarpment both north and south of the lagoon, and is offset to the east by a few tens of metres. As such, the resistivity contrast is interpreted to mark the plane of the Kurrajong Fault, with higher resistivity 

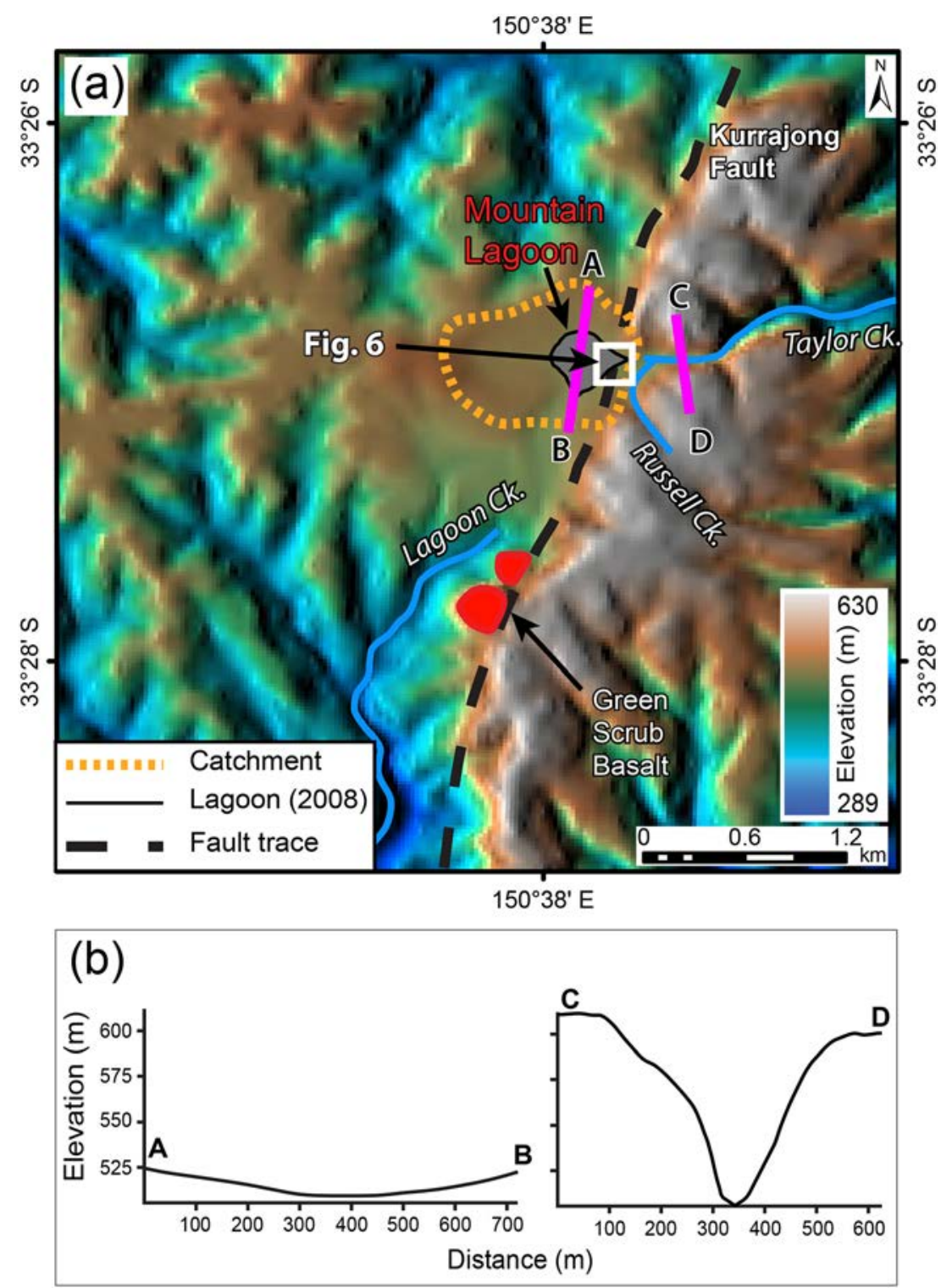

Figure 5. (a) Digital elevation model (NSW Department of Land and Property Information: $25 \mathrm{~m}$ ) of the Mountain Lagoon area. Drainage lines and locations of Mountain Lagoon and Green Scrub Basalt are shown. The catchment boundary of the lagoon (heavy orange dotted line) and inferred location of the Kurrajong Fault (heavy black dashed line) are also marked. (b) Topographic cross-sections showing the steep-sided V-notch (C-D) east of the Kurrajong Fault versus the subdued relief of the Mountain Lagoon basin (A-B). Refer to (a) for cross-section locations.

Hawkesbury Sandstone to the east, and less resistive basin sediments to the west. The location of the resistivity boundary, and by inference the fault plane, to the east of the topographic escarpment supports the idea that the Kurrajong Fault is vertical to steeply east-dipping.

In the northern part of the survey area and underlying the easternmost point of the lagoon, resistivity and drill-hole data indicate the presence of a buried east-west trending feature apparently incised into resistive bedrock on the up-thrown side of the fault (Figure 7a). This feature is prominent only at depths below $10 \mathrm{~m}$, and located $\sim 20 \mathrm{~m}$ to the south of the current topographic low between the lagoon and the headwaters of Taylor Creek. Drilling at the northern margin of the feature intersected predominantly sandy sediments overlying weathered sandstone bedrock at $7.4 \mathrm{~m}$ depth (DH04 - Figures $7 \mathrm{a}$ and 7b; see also Figure 9). We speculate that this incision feature is a palaeochannel linking the basin to Taylor Creek (cf. Grady and Hogbin, 1926) that was beheaded by movement on the Kurrajong Fault, and subsequently modified by headward propagation of knick points from its eastern and western ends. At depths shallower than $10 \mathrm{~m}$, we interpret the broader high resistivity response (similar to that seen in the upper $5-10 \mathrm{~m}$ of Lines 7 and 8 in Figures $7 \mathrm{~b}$ and $7 \mathrm{c}$ ), to reflect the generally coarse nature of colluvial and alluvial fan sediments descending from Russell Creek and the scarp to the north. These sediments may have contributed to burying the uplifted fault barrier and the incised palaeochannel.

Outliers of more resistive material $40-55 \mathrm{~m}$ to the west of the fault barrier are apparent at depths below $10 \mathrm{~m}$ and become prominent below $20 \mathrm{~m}$ (e.g. DH03 - Figure 7a and 7c). These outliers have an approximately linear western margin and might reflect buried bedrock topple-blocks or bedrock-sourced colluvium shed from the scarp into the basin. Alternatively, the resistivity contrast may reflect bedrock elevated (east-side up) across a splay of the main fault. This interpretation is consistent with the roughly linear western margin of the resistivity high.

Having established the location of the buried Kurrajong Fault trace on the eastern side of the basin, a ground-penetrating radar (GPR) survey was completed by Douglas Partners Pty Ltd, Melbourne, Australia, across the same area to establish the stratigraphy of the hill-slope and lacustrine/alluvial deposits 


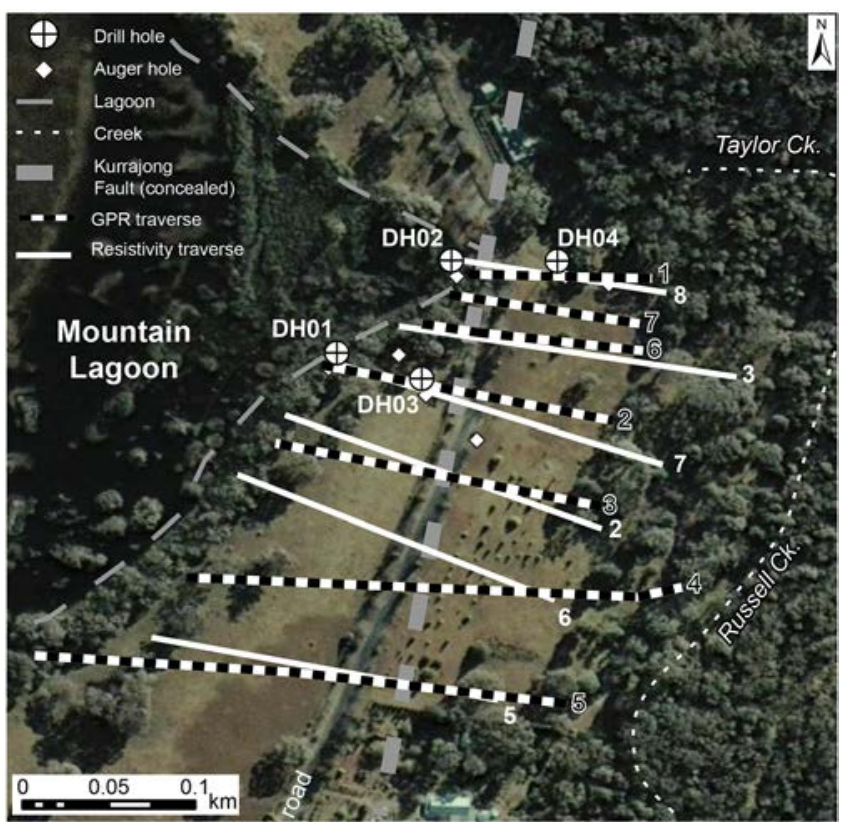

Figure 6. Aerial view of the eastern side of Mountain Lagoon showing the location of drill holes, auger holes, ground penetrating radar (GPR) and electrical resistivity survey traverses. Line numbers for resistivity and GPR traverses are indicated. This figure is available in colour online at wileyonlinelibrary.com/journal/espl

on both sides of the fault, and to identify any tectonic displacement of these strata. Transects along which the GPR profiling data were collected are shown in Figure 6. As a result of prior knowledge about fault location the GPR transects were shorter than those for the resistivity survey. A Mala Ramac GPR system was employed, and after a series of trial lines testing 25, 100 and $250 \mathrm{MHz}$ antennae, a $250 \mathrm{MHz}$ shielded antenna was used to collect six profiles, with two of the profiles subsequently repeated using a $100 \mathrm{MHz}$ antenna. Data were processed using Mala Ramac Ground Vision software.

Figure 8 shows the radargram for GPR Profile 7 - the northernmost GPR survey traverse (refer to Figure 6). A number of semi-continuous undulating or dipping reflectors occur at depths of up to $\sim 6 \mathrm{~m}$ (and deeper in the west). Correlations with drill-holes DH01/DH02 and DH04 (Figure 9; see next section) indicate that these reflections relate to denser clay horizons within the sedimentary sequence. Bedrock was encountered at a depth of $7.4 \mathrm{~m}$ in $\mathrm{DHO} 4$ (Figures 8 and 9), however a strong bedrock reflection is not apparent on this or any other GPR profile. A zone of few to no deep reflections at depths below $\sim 5 \mathrm{~m}$ occurs east of the road on Profile 7 (Figure 8). This low response zone, which continues westward towards the road in the profiles further south, could be interpreted as shallow, relatively 'old' sediment, draped over the upthrust bedrock block (John Lean, Principal Geophysicist, Douglas Partners Pty Ltd, personal communication, 2009). Alternatively, and our preferred interpretation, is that this low response zone is the result of weak or scattered reflections from an irregular bedrock surface. This is suggested by its approximate depthwise co-location with the bedrock identified in the base of $\mathrm{DH} 04$, and its spatial association with the up-thrown bedrock block, as interpreted from the resistivity. This is in contrast to the strong basal reflections at the western end of the profile (Figure 8) that are correlated with thick clay horizons within the basin proper, as identified in drill-hole DH01. Strong but complex reflection patterns to the east are interpreted as younger sediments in a depositional channel environment relating to alluvial and colluvial packages associated with the Russell Creek alluvial fan.
The three northernmost GPR traverses (see Figure 6) overlie the subsurface incision feature identified in the resistivity data (Figure 7). These GPR profiles show strongly basinward-dipping reflectors at their western end (e.g. Figure 8). Erosional truncation and onlap of strata within this dipping package is evident, consistent with infill of the incision feature by sediment sourced from the Russell Creek fan and adjacent slopes. The dipping package of strata is not displaced across the position of the Kurrajong Fault plane. The basinward-dipping sediment package is absent, or very subtle, south of the incision feature imaged in the resistivity data. As such, we consider the dip more likely to relate to drape of sediments over pre-existing topography rather than to tectonic tilting.

\section{Basin stratigraphy}

In order to validate the interpretations from the geophysical surveys, establish sediment thickness and characteristics on both sides of the fault, and acquire samples for geochronology, a drilling investigation was completed using a track-mounted Geoprobe drill rig. A series of $60 \mathrm{~mm}$ diameter cores were collected from four drill-holes (DH01, DH02, DH03, DH04) on the eastern side of the lagoon (Figure 9; see Figure 6). Duplicate cores were collected at several of the sites for optically-stimulated luminescence (OSL) dating.

Detailed logging of the cores (Figure 9) confirmed the general stratigraphy and regolith geology as interpreted from the geophysics and field investigations. This included numerous layers of finely $(<2 \mathrm{~mm})$ laminated brown to grey and occasionally black, light- to heavy-clays (many with appreciable organic content) of dominantly (shallow) lacustrine origin. These clays interfinger with moderately- to poorly-sorted, medium- to coarse sub-angular quartz sands and loamy sands, which are associated with colluvial slopes and alluvial fans (e.g. Russell Creek) sourced from the fault scarp to the east. As might be expected, lacustrine clays become more prevalent in the profiles closer to the lagoon margin (i.e. DH01, DH02 - Figure 9).

Drill-hole DH01 revealed $23 \mathrm{~m}$ of sediments overlying shale bedrock on the west side of the Kurrajong Fault with most of the section appearing to be of lacustrine origin. Drill-hole DH04 confirmed that up to $7.4 \mathrm{~m}$ of sediments overlie sandstone on the up-thrown block immediately north of the buried 'palaeochannel' (see Figure 7). The Mountain Lagoon basin thus contains up to $15 \mathrm{~m}$ of sediments trapped behind a bedrock barrier presumed to be uplifted by movement on the Kurrajong Fault. The regolith materials in $\mathrm{DHO} 3$ and $\mathrm{DHO} 4$ (Figure 9) contain a greater proportion of coarse sandy sediment, suggesting relatively greater input from the sandstonedominated fault scarp via colluvial and alluvial fan processes, and also reflecting their higher elevation landscape position (Figures 6 and 7). The sedimentary sequence within $\mathrm{DH} 04$ also includes an appreciable lacustrine component (Figure 9).

\section{Age constraints on basin sediments}

Having established sediment thickness distribution across the fault and the characteristics of the dominant strata, samples from the drill cores were taken for geochronological analysis in order to constrain depositional and/or re-working ages for layers within the stratigraphic sequence. Organicrich clay layers were sampled for palynological analysis, while sands from the coarse layers were sampled from the sealed drill cores for OSL dating. 

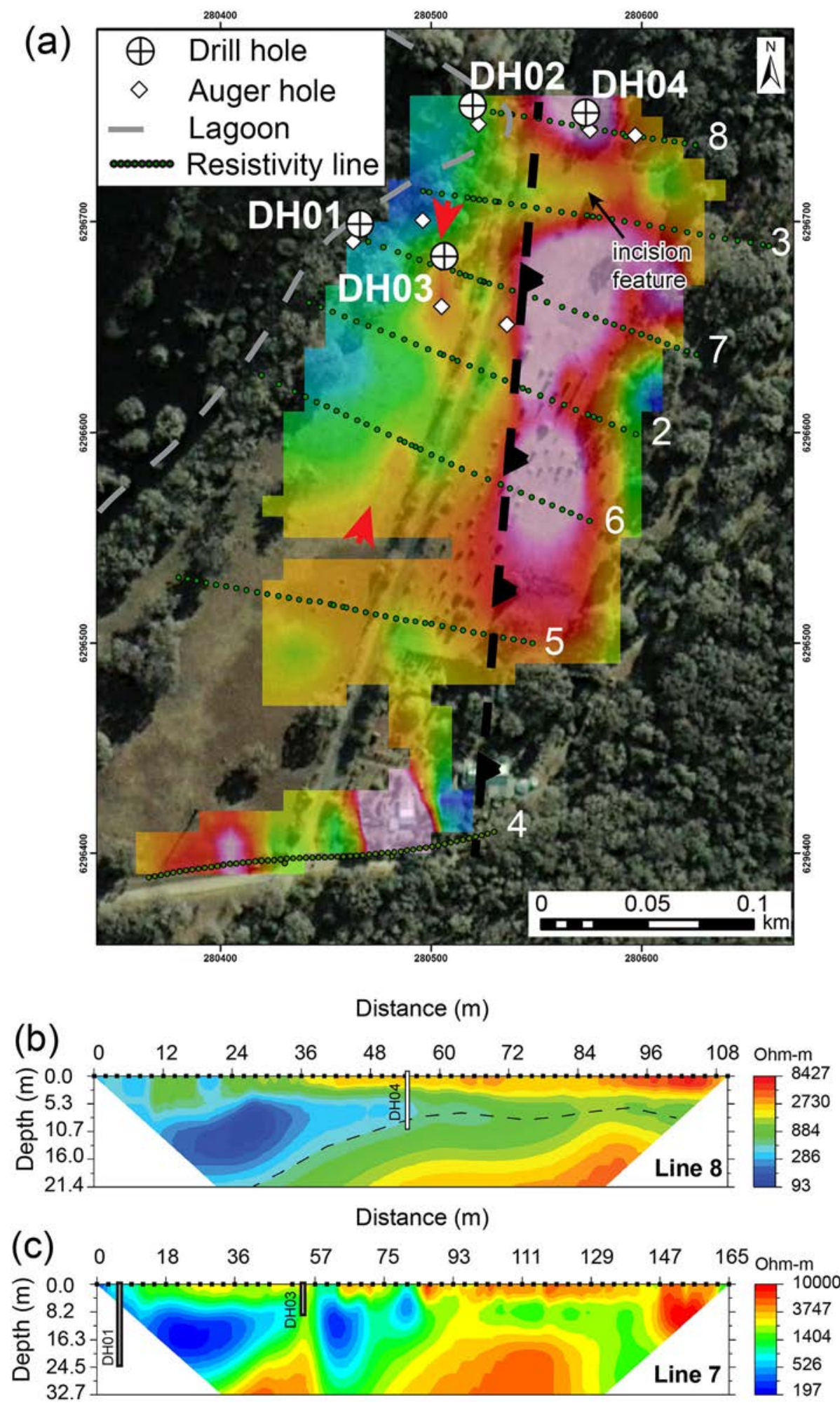

Figure 7. (a) Electrical resistivity at $20 \mathrm{~m}$ depth below ground surface modelled from survey data (blue $=$ low; pink/red $=$ high - refer to (b) and (c) for resistivity scale). The strong resistivity contrast between east and west indicates the location of the concealed Kurrajong Fault (black dashed line) and a possible western splay (red arrows). An incision feature in the up-thrown block on the eastern side of the Kurrajong Fault between resistivity Lines 3 and 8 is apparent at depths below $10 \mathrm{~m}$. (b) Vertical depth section through resistivity Line 8 showing thickening of basin fill to the west and interpreted bedrock surface as validated by drill-hole DH04. (c) Vertical depth section through resistivity Line 7 showing low resistivity sediments associated with the main basin depocentre (0-36 m horizontal) and more localized deposition east of the interpreted fault splay (57-93 m horizontal). Higher resistivity material at depths less than $\sim 10 \mathrm{~m}$ in both (b) and (c) is interpreted as coarse clastic input from the Russell Creek alluvial fan and surrounding slopes.

Optically-stimulated luminescence (OSL) geochronology Samples for OSL were collected from the sealed drill cores under subdued red light. There was no disruption of the laminated sediments, showing that mixing had not occurred during core extraction. The analytical procedures employed in sampling, processing and analysing the core materials were as detailed in Quigley et al. (2006).

Dose rate data and optical ages for samples from the drill cores are presented in Table I. The OSL sample ages are presented in conjunction with the palynology data in Figure 10. 


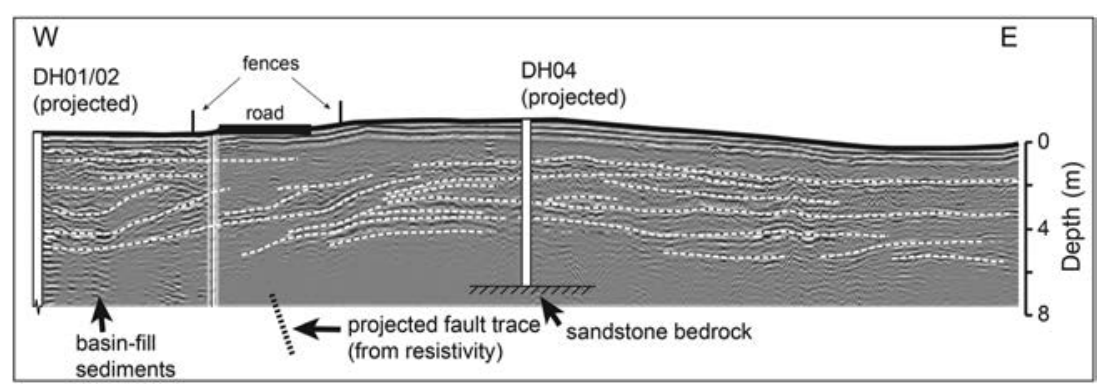

Figure 8. Radargram collected along the northernmost GPR survey line (Line 1 - see Figure 6). Silt and clay layers represent the strongest reflectors (white dashed lines). Note the apparent drape of sediment with gentle bedding dips to the east and west over the buried up-thrown sandstone ridge, and stacked responses from basin-fill sediments in the west of the image.

$\mathrm{DH} 01$

Depth $(m)$

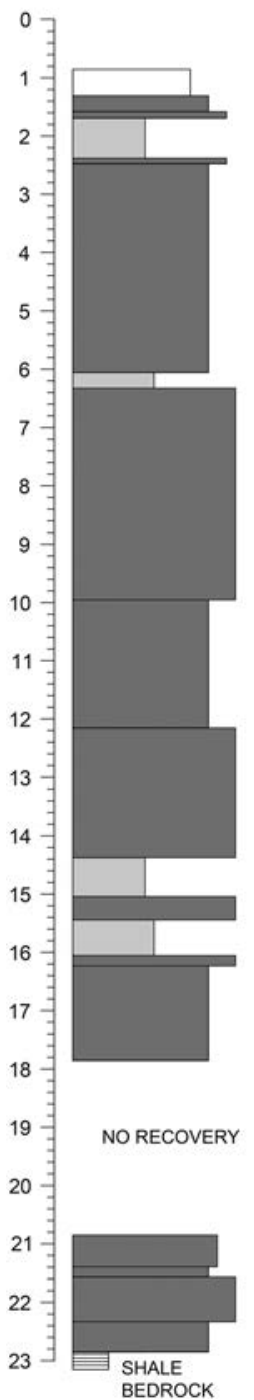

$\mathrm{DH} 02$

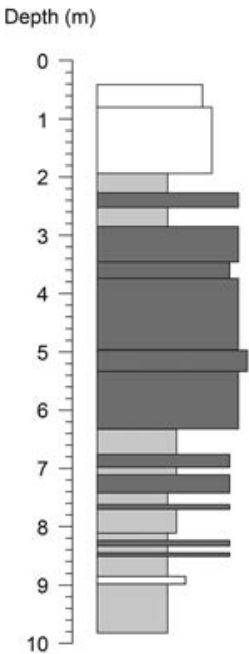

$\mathrm{DH} 03$

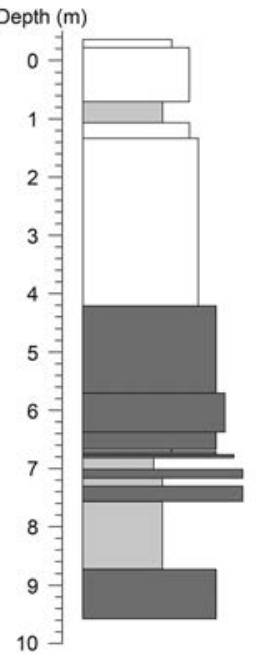

$\mathrm{DH} 04$

Depth $(m)$

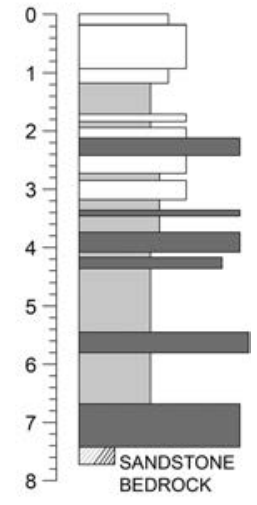

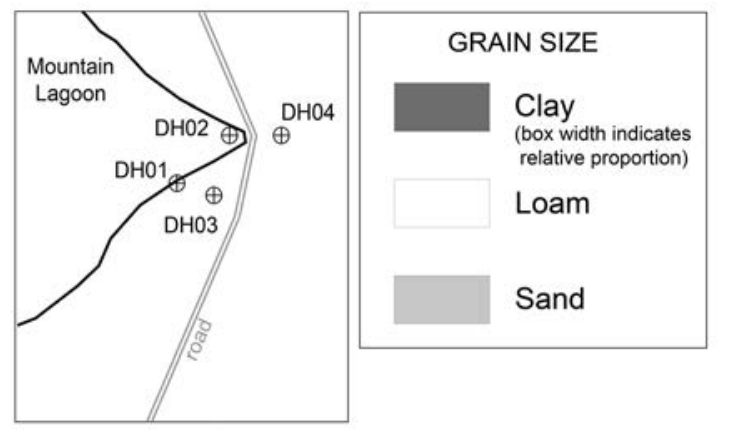

Figure 9. Detailed drill core logs for drill holes DH01 to DH04 showing the dominance of fine-grained (clay) materials within the basin fill sediments. Field textures are expressed as approximate grain-size classes. Inset shows locations relative to the eastern margin of the lagoon. Note: Layer thicknesses for drill holes DH01 to DH03 have been normalized to DH04. Top-of-hole relative levels reflect true elevation differences surveyed from collar heights.

Ages of $20 \pm 2 \mathrm{ka}(1.2 \mathrm{~m})$ and $27 \pm 5 \mathrm{ka}(2.1 \mathrm{~m})$ for sediments in the upper $2 \mathrm{~m}$ of drill-hole $\mathrm{DHO} 2$ are consistent with the data presented by Robbie and Martin (2007), who constrain the upper $1 \mathrm{~m}$ of lake sediments to $\sim 23 \mathrm{ka}$. A general progression of increasing OSL age with depth, i.e. $\sim 20 \mathrm{ka}$ at $1.2 \mathrm{~m}$ through to $\sim 80 \mathrm{ka}$ at $5.1 \mathrm{~m}$, is noted in the sediments from
DHO2 and DHO4 (Figure 10); a trend consistent with the palynology data.

In DH01 below a depth of $\sim 5 \mathrm{~m}$ there is a significant increase in the age of the sediment compared to similar depths in neighbouring drill-holes. Only the uppermost sample yielded a non-saturated OSL age of $172 \pm 25 \mathrm{ka}(5.4 \mathrm{~m})$. It is possible 


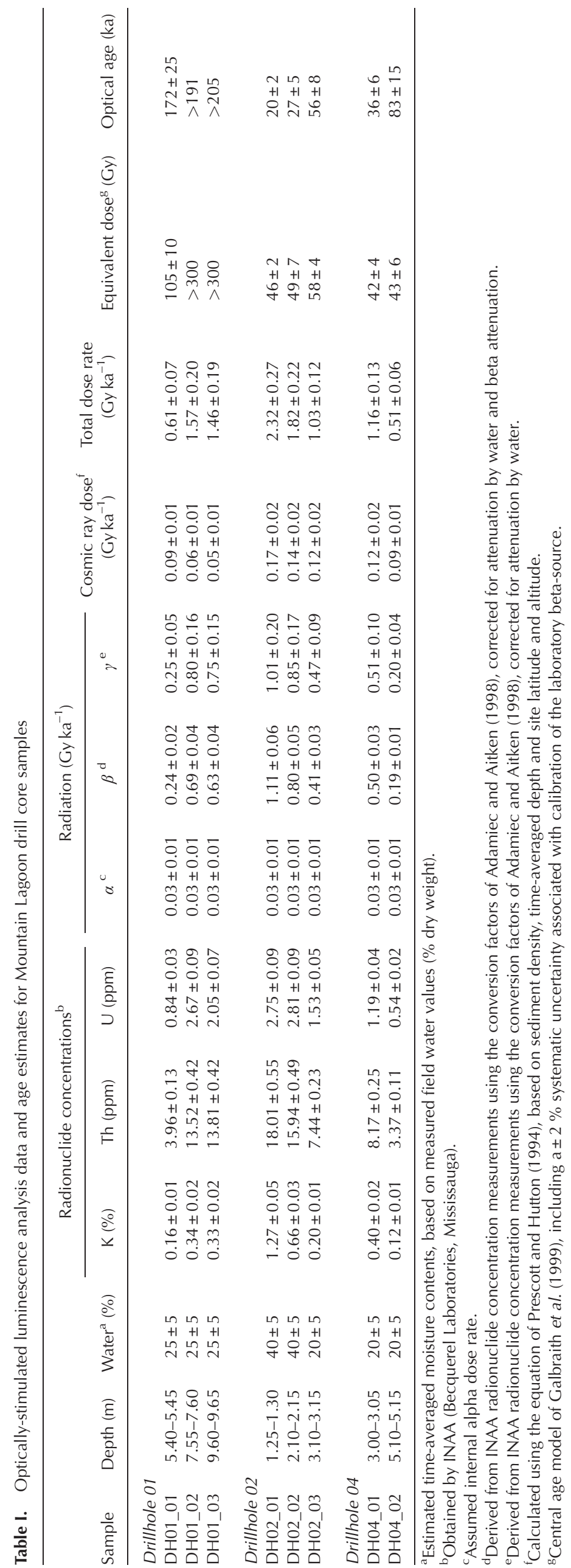




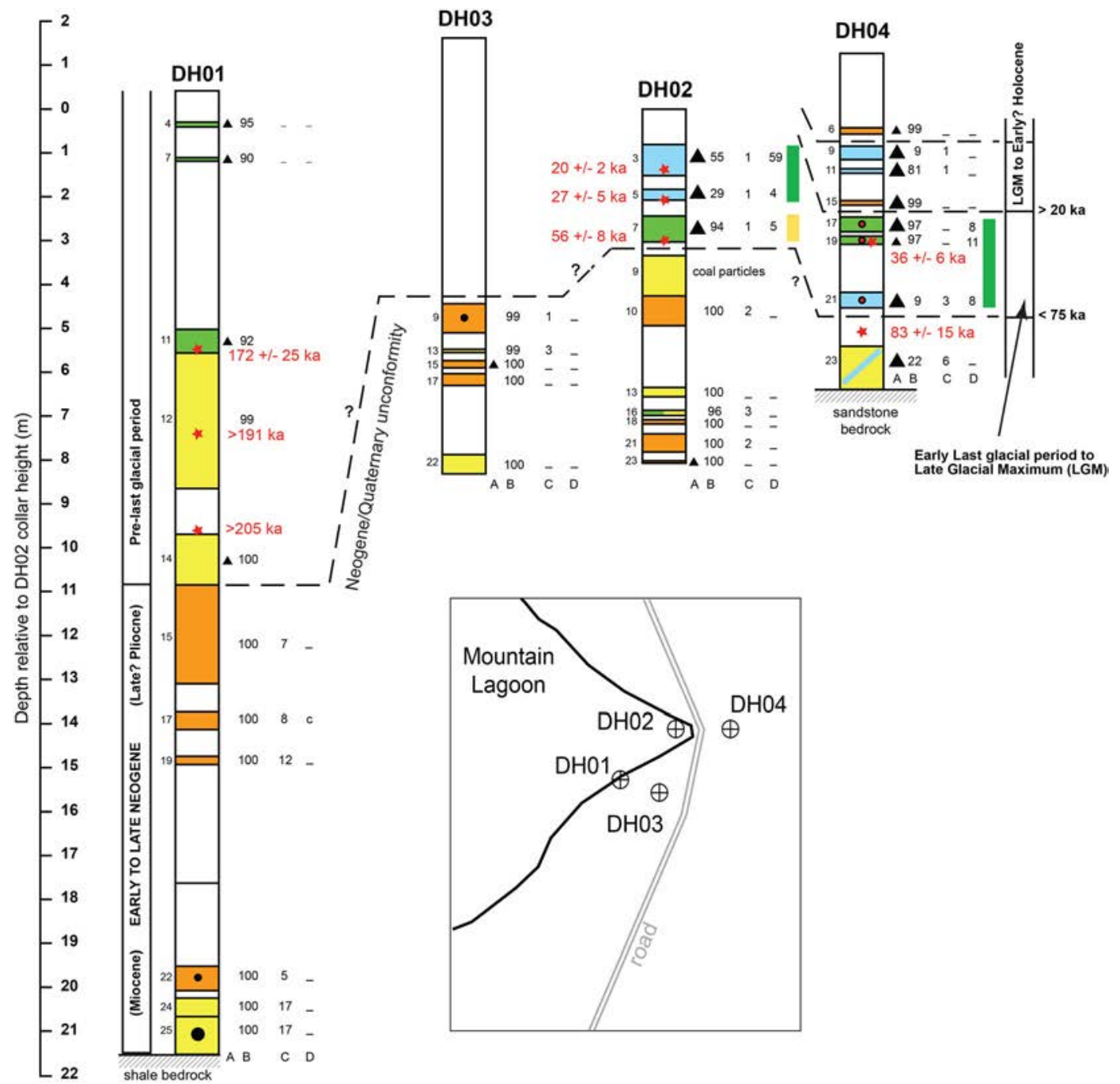

\begin{tabular}{|c|c|c|c|c|}
\hline \begin{tabular}{|l} 
LAKE \\
(free-floating algae dominant)
\end{tabular} & A & $\begin{array}{l}\text { Free-floating algae dominant } \\
\text { Free-floating algae uncommon }\end{array}$ & & $\begin{array}{l}\text { Tree \& shrub pollen types common } \\
\text { relative to herbaceous pollen types }\end{array}$ \\
\hline $\begin{array}{l}\text { FEN } \\
\text { (free-floating algae uncommon) }\end{array}$ & B & $\begin{array}{l}\text { Ratio of terrestrial organic } \\
\text { particles to free-floating algae }\end{array}$ & & $\begin{array}{l}\text { Restionaceae (reed) pollen common } \\
\text { relative to woody pollen types }\end{array}$ \\
\hline $\begin{array}{l}\text { ALLUVIAL FAN } \\
\text { (dominant terrestrial organics) }\end{array}$ & C & $\begin{array}{l}\text { Number of Nothofagidites } \\
\text { pollen grains recorded in sample }\end{array}$ & & $\begin{array}{l}\text { Re-worked Permo-Triassic gymno- } \\
\text { sperm pollent common in sample }\end{array}$ \\
\hline $\begin{array}{l}\text { WEATHERED INTERVAL } \\
\text { (minimal organic yield) }\end{array}$ & D & $\begin{array}{l}\text { Relative abundance (\%) of } \\
\text { Tubulifloridites pleistocenicus }\end{array}$ & $\bullet$ & $\begin{array}{l}\text { Re-worked Permo-Triassic gymno- } \\
\text { sperm pollent rare in sample }\end{array}$ \\
\hline \multicolumn{3}{|l|}{ OSL sample } & 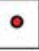 & $\begin{array}{l}\text { Polymeria-type (Perfotricolpites } \\
\text { digitalis) pollen present in sample }\end{array}$ \\
\hline
\end{tabular}

Figure 10. Plant microfossil (palynostratigraphic) data for samples from the four drill cores collected along the eastern margin of Mountain Lagoon. Optically-stimulated luminecence (OSL) ages (refer to Table I) are shown as red stars. Values on the left-hand side of the columns represent raw microfossil counts from the individual samples, while fields A-D on the right hand side of columns relate to items A-D in the legend. See Supplementary Information for details of the plant microfossil analysis.

that the package between this sample, and the weathered interval at $\sim 11.3 \mathrm{~m}$ (see Figure 10), was deposited during Marine Isotope Stage 7 (c. 240 ka - e.g. Murray-Wallace, 2002).

Palynostratigraphy

The uppermost metre of sediment infilling Mountain Lagoon represents the period since the Last Glacial Maximum (c. $20 \mathrm{ka}$ - Robbie and Martin, 2007). In contrast, and with two possible exceptions (the uppermost samples in $\mathrm{DH} 01$ and DH04), all palynostratigraphic age determinations in this study (Macphail, 2013; see Supporting Information) are Last Glacial Maximum or older (Figure 10). This is based on OSL ages and comparison against presence/absence criteria developed for the Gippsland and Murray-Darling Basins, supported by data from northeast Queensland and central Victoria (Macphail, 1997, 1999; Partridge, 1999; Sniderman et al., 2007). Yields of fossil spores and pollen in oxidized, filtered $(5 \mu \mathrm{m})$ organic extracts from drill-holes $\mathrm{DH} 01$ to $\mathrm{DH} 04$ were mostly low to very low but adequate to show that sediment began accumulating in the basin in the Neogene, possibly as early as the Miocene, and continued intermittently into the Last Glacial period. The presence of thermally-altered Permo-Triassic gymnosperm pollen in the same strata provides circumstantial evidence that sediment accumulation post-dates the 18.8 Ma emplacement of the Green Scrub Basalt flow (Wellman and McDougall, 1974), and supports the assertion that the basalt flow was previously more extensive.

Significant findings are:

1. A $\sim 5.5 \mathrm{~m}$ thick deeply weathered interval dated by OSL to a minimum age of $172 \mathrm{ka}$ occurs between $11 \mathrm{~m}$ and $5.5 \mathrm{~m}$ below ground surface in drill-hole $\mathrm{DH} 01$. While its age limits are not well constrained, the base of this interval 
may correspond to unconformity surfaces identified in DHO2 and DH04, and imaged in the GPR data. In DH02, the unconformity reflects a time gap ranging from Late Pliocene (Piacenzian) to Late Pleistocene, and in DH04 from Early Pliocene (Zanclean) to Late Pleistocene. Assuming that a pollen grain of the extinct species Reevesiapollis reticulatus is in situ at $6.7-7.4 \mathrm{~m}$ below ground surface in $\mathrm{DH} 04$ (see Supporting Information), then the sample provides compelling evidence that accommodation space was present on the eastern side of the Kurrajong Fault sometime before or during the Early Pliocene (Zanclean). It is probable that at this time the basin was part of a more extensive 'lagoon' with a depocentre on the western side of the fault (cf. Henderson, 1975). The same data provide circumstantial evidence that displacement on the Kurrajong Fault had occurred before or during the Early Pliocene (Zanclean) since it is unlikely that the sandstone fault barrier was deeply buried at this time.

2. Plant microfossils in samples from above the unconformity surface indicate that fen and lacustrine environments are prevalent during the Last Glacial Period and the 'postglacial' period. (Figure 10; see Supporting Information). Independently dated assemblages indicate sedimentation occurred from the Last Glacial Period to Last Glacial Maximum in DHO2 (c. 56-20 ka) and from before the Last Glacial Maximum to the Late Pleistocene or Early Holocene in $\mathrm{DHO} 4$ (c. 36 to $<20 \mathrm{ka}$ ). The underlying weathered interval in $\mathrm{DHO} 4$ dates to the early stages of the Last Glacial Period based on an OSL date of $83 \pm 15 \mathrm{ka}$ for sediments at $5.1 \mathrm{~m}$ depth below ground surface. Whether a palaeolake was present at Mountain Lagoon during the Early to Middle Pleistocene is unknown.

3. Unlike the Quaternary intervals, Neogene sedimentation shows evidence for significant coarse clastic terrestrial input suggesting increased erosion. Many of the weathered sections are dominated by coarse sediment and show abundant evidence for groundwater interflow, including deposition of secondary iron oxides and enhanced mineral weathering. Not surprisingly these intervals are relatively poorly represented by plant microfossils. Accordingly a matching set of organic-rich core samples was analysed to determine any evidence for non-marine ostracods, which might indicate prolonged periods of high lake level. None were found in any of the samples, consistent with palynological evidence for fluctuating lake levels within the basin.

\section{Discussion}

\section{The Neogene to Holocene evolution of Mountain Lagoon}

Sediments overlying Triassic shale bedrock at the base of the sequence infilling the Mountain Lagoon basin are no older than Late Paleogene and are most likely to be Early Neogene in age. The presence of thermally-altered Permo-Triassic gymnosperm pollen in these basal strata provides circumstantial evidence that sediment accumulation postdates the $18.8 \mathrm{Ma}$ emplacement of the basalt at Green Scrub (Wellman and McDougall, 1974), which was presumably of greater original extent (van der Beek et al., 2001). However, the lowermost strata in all drill-holes preserve pollen assemblages dominated by terrestrial organics, suggesting that deposition relating to alluvial fan processes dominated over lacustrine deposition. This is consistent with the existence of relief related to the Kurrajong Fault prior to $18.8 \mathrm{Ma}$, with the additional implication being that the Green Scrub Basalt pooled against extant topography. The relative elevation of shale bedrock on the western side of the fault and sandstone bedrock on the eastern side of the fault indicates that only $\sim 15 \mathrm{~m}$ of the $130 \mathrm{~m}$ of throw across the Kurrajong Fault postdates the onset of sedimentation in the Mountain Lagoon basin.

The top of the Neogene section does not appear to be vertically displaced between drill-hole $\mathrm{DHO}$ and drill-holes DH02/DH03 (Figure 10) across the position of the main fault imaged in the resistivity data. This interpretation is supported by the GPR data, which shows the semi-continuous reflectors representing shallow undeformed sediments draped over the uplifted bedrock block and extending across the position of the fault. In contrast, the top of the Neogene section varies by 6 to $7 \mathrm{~m}$ vertically in the $\sim 40 \mathrm{~m}$ horizontal interval between DH01 and DH02/DH03. This interval crosses the western quasi-linear margin of the region of elevated resistivity response occurring west of the main fault (Figure 8). A plausible explanation is that, following the deposition of the drape of alluvial sediments across the main fault trace in the Late Neogene, the locus of deformation on the Kurrajong Fault migrated west from the main fault imaged in the resistivity, to a western splay. The accommodation space created by movement on this western splay was subsequently filled by Quaternary alluvial and lacustrine sediments.

The presence of a subsurface incision feature in the sandstone bedrock on the up-thrown eastern side of the Kurrajong Fault suggests a significant hiatus separating the last episode of Neogene movement on the main fault, and that on the western splay. This interpretation is consistent with the presence of the weathered interval at the Neogene/Quaternary unconformity (Figure 10). Basal Quaternary sediments in DH04 are older than c. $83 \mathrm{ka}$, but their age is otherwise not well constrained, as pollen was not preserved and OSL samples were saturated. OSL dating of unbroken strata (verified using GPR) overlying the Kurrajong Fault traces at Mountain Lagoon suggests the most recent deformation event predates $172 \pm 25$ ka (sample DH01_01 - Table I). Our preferred interpretation is that several temporally closely-spaced seismic events displaced the top of the Neogene section in the Mountain Lagoon basin prior to $172 \pm 25 \mathrm{ka}$. This uplift created accommodation space within the basin, and may also have resulted in enhanced alluvial fan activity, particularly relating to Russell Creek, which buried the channel at the north-eastern edge of the lagoon and contributed significant volumes of sediment to the basin.

The GPR survey results suggest that, while a number of geomorphic processes may have contributed to the evolution of the stratigraphic sequence imaged in the upper $8 \mathrm{~m}$, there is no evidence preserved for either syn- or post-depositional deformation of these sediments. The distribution and dip of the strata draping the buried sandstone ridge are consistent with an alluvial fan-dominated hillslope environment shedding sediment from the sandstone escarpment to the east, interfingering with lacustrine sediments (stronger GPR reflectors) that indicate periods of higher water level, and perhaps greater areal extent of the lagoon (cf. Henderson, 1975). The dominance of fen and lacustrine facies up-section implies relatively humid environments during the Early Pliocene into, but not during, the Last Glacial Maximum at c. $20 \mathrm{ka}$, and again in the Holocene (Robbie and Martin, 2007; this study). The relatively consistent gradation in the sediment ages with depth in the upper few metres of the lagoon suggests that climate has been the dominant control on sedimentation during the Late Pleistocene and Holocene. Alternatively, a model of relatively steady displacement on the Kurrajong Fault, coupled with comparable rates of erosion and deposition, could be invoked. 
However, the dominance of lacustrine sediments in the upper sections does not support such a hypothesis, which would be expected to result in episodic input of clastic sediments from the adjacent slopes. Accordingly, it is inferred that no significant movement has occurred on the Kurrajong Fault since the Middle Pleistocene.

\section{Implications for the evolution of the LSC}

Burralow Swamp (see Figure 4) is the only basin within the LSC apart from Mountain Lagoon to have been investigated in any detail (Rawson, 1990; Rawson and Clark, 2009). At Burralow Swamp, the deepest borehole (B-C4) intersected $14 \mathrm{~m}$ of sediment without encountering bedrock. A spatially extensive 6-7 $\mathrm{m}$ thick medium- to heavy-clay layer, denoted the Tabaraga Unit, was defined in the deepest part of the basin. This unit rapidly thins downstream and pinches out against a steeply rising bedrock barrier considered to relate to the Burralow Fault (Rawson, 1990). Fossil pollen assemblages preserved in this unit lacked typical Neogene taxa, including Nothofagus, but included Tubulifloridites pleistocenicus, a morphospecies that becomes rare or absent following the Last Glacial Maximum (see Figure 10; Rawson, 1990). Rawson and Clark (2009) contend that this deposit is the result of tectonic rejuvenation whereby movement on the Burralow Fault imposed a new elevated base-level, leading to temporary damming of the drainage line. Sandy strata extending from the top of the Tabaraga Unit to the surface are interpreted to have been deposited during the progressive re-establishment of stream channel equilibrium. This evidence for Late Pleistocene damming of Burralow Creek is consistent with the data from Mountain Lagoon, where the top of the Neogene section has been displaced by a similar amount to the thickness of the Tabaraga Unit. The similarity in timing and displacement between the Kurrajong and Burralow faults implies a shared rupture history, which would suggest structural linkage between faults of the KFS. The en echelon arrangement of faults comprising the KFS (Branagan and Pedram, 1990), and seismic reflection data over the south-central section of the LSC (Herbert, 1989), supports this interpretation.

A diversity of opinions exist regarding potential structural interactions and linkages between faults of the KFS and the east-facing monoclines and faults associated with the eastern range front of the Blue Mountains (e.g. Herbert, 1989; Branagan and Pedram, 1990; Pickett and Bishop, 1992; Bray et al., 2010; Fergusson et al., 2011). Although no master fault has been imaged or observed beneath the Lapstone Monocline (Herbert, 1989), monoclines are typically considered to form as propagation folds above faults at greater depth (e.g. Suppe and Medwedeff, 1984; Jamison, 1987; McBride and Nelson, 1999; Tindall and Davis, 1999). The spatial association of the Lapstone Monocline and the KFS can be interpreted in terms of a shallowly-dipping reverse fault underlying the monocline, with the fault dip steepening as it emerges from the underlying Lachlan Fold Belt basement into overlying Sydney Basin strata, and generating antithetic splay faults (e.g. IGNS, 1999). Circumstantial evidence for faulting related to the Lapstone Monocline is seen at its southern end, where folding is accompanied by west-dipping faulting (e.g. Mount Riverview and Hawkesbury Lookout Faults) (Branagan and Pedram, 1990; Fergusson et al., 2011).

Sympathetic movement of the KFS and east-facing monoclines in the central LSC could also explain the coincidence of swamps and shallow basins west of the KFS and ubiquitous over-steepening of stream profiles across the adjacent monoclines (e.g. Rawson, 1990; Kirkby et al., 2009). However, the link is not compelling as the stream profile over-steepening might plausibly relate to alternative mechanisms, such as lithological and/or structural control, or renewal of knick-points to the east of the monoclines as streams incised through Ashfield Shale into the more resistant Hawkesbury Sandstone (Seidl et al., 1996; Kirkby et al., 2009). Irrespective, the geologic data favour a largely pre-Neogene origin for the majority of structural relief of the LSC, as suggested by many previous workers (e.g. Pickett and Bishop, 1992; van der Beek et al., 2001; Bray et al., 2010; Fergusson et al., 2011). The present-day physiography of the eastern range front of the Blue Mountains, represented by up to several hundred metres of relief, is therefore likely to dominantly reflect the progressive erosional emergence over the last c. 20 Ma of resistant, faulted and folded sandstone from beneath a cover of more readily erodible shale (e.g. Pickett and Bishop, 1992). Removal of shale immediately west of the west-facing fault scarps occurred concurrently with removal from the eastern side of the monocline, exposing the 'ramp' of the lower Blue Mountains on the west and the front of the monocline on the east, both corresponding closely to the top of the Hawkesbury Sandstone.

Despite its modest scale, the evidence from the LSC for two separate periods of Neogene and younger structural relief building is compelling. This apparent temporal clustering of fault activity in the LSC is similar to that documented elsewhere in eastern Australia, including regions distal to south-eastern highlands. For example, the Cadell Fault, located within the Murray Basin over $500 \mathrm{~km}$ west of the highlands (Clark et al., 2012; McPherson et al., 2012), provides evidence for two periods of relief building. The first is constrained to the Mio-Pliocene, and the second to the Upper Pleistocene ( 70-20 ka), with each period involving approximately $20 \mathrm{~m}$ of uplift (McPherson et al., 2012). The LSC data therefore adds to an emerging body of evidence suggesting that the temporal clustering behaviour observed from individual fault studies in Australia may reflect essentially continuous, yet relatively minor, tectonic activity from Late Miocene to Recent being punctuated by 'pulses' of activity in specific deforming regions (e.g. Quigley et al., 2010; Norvick, 2011; Clark et al., 2012). It is possible that the initial and most widespread phase of Cenozoic activity might relate to the pulse of deformation recorded in south-eastern and southern Australian offshore basins in the interval 10-5 Ma associated with the reorganization of the crustal stress field to its present configuration (Dickinson et al., 2001; Norvick and Smith, 2001, Dickinson et al., 2002; Sandiford et al., 2004; Hillis et al., 2008).

\section{A punctuated and spatially variable Kosciuszko Uplift?}

Based upon a study of Paleogene basalt distribution and an appraisal of AFTT ages in the Victorian highlands (e.g. Kohn et al., 1999; O'Sullivan et al., 1999), Vandenberg (2010) concluded that the total amount of Neogene uplift of the south-eastern highlands was on the order of no more than a few hundred metres, broadly consistent with modelled uplift rates resulting from lithospheric shortening (Braun et al., 2009) and mantle-driven dynamic topography (Heine et al., 2010; Czarnota et al., 2013, 2014). Holdgate et al. (2011) dispute key points of the Vandenberg (2010) argument, maintaining that up to a kilometre of relief may have been generated since the Eocene, which Holdgate and colleagues termed a 'resurrected' Kosciuszko Uplift. Holdgate et al. (2008) invoke block faulting on a series of northeast-trending faults, evident as lineaments in digital elevation data, as the driver of uplift. However, these features typically strike at a 
moderate- to high-angle to the few faults in the south-eastern highlands with documented significant Cenozoic displacements (e.g. Vandenberg, 2010; Clark et al., 2012). Furthermore, the proportion of displacement on these documented structures that might be Neogene or younger is typically unknown. An exception is the Lake George Fault, which is associated with at least $190 \mathrm{~m}$ of Neogene vertical displacement. This contributed to the formation of a $150 \mathrm{~m}$ deep depocentre and the building of a 100-150m high scarp (Singh et al., 1981; Abell, 1985, 1991). That is, a minimum of $\sim 70 \%$ of the total displacement on this fault can be considered to be Neogene or younger.

Based upon an appraisal of the physiography alone, the eastern range front faults of the Blue Mountains (i.e. LSC) might be considered analogous to large Cenozoic fault structures or complexes elsewhere in the south-eastern highlands, such as the Lake George Fault, and so might also constitute evidence for the Holdgate et al. (2011) post-Eocene uplift. However, the present study demonstrates that only $\sim 10 \%$ of the uplift across the LSC post-dates the Eocene. Accordingly, presentday relief in this intraplate passive margin setting provides little guidance as to the timing and scale of fault activity. A further implication of this comparison is that we might expect significant variability in the timing and degree of deformation on other faults exhibiting Cenozoic displacement in the southeastern highlands. That is, the post-Eocene component of the Kosciuszko Uplift, at least, exhibited large spatial variability in the magnitude of uplift.

The results from the LSC suggest that a significant proportion of the relief generation of the southeast Australian passive margin at this location was attained by episodic (i.e. Paleogene and Neogene to Recent) post-rift uplift unrelated to the process of rifting and continental separation, similar to the emerging body of evidence from other elevated passive margins worldwide (e.g. Japsen et al., 2006, 2009). However, our data also suggest that significant spatial variability exists in the magnitude of post-rift uplift along the southeast Australian elevated passive margin. In addition, it might be expected that locations exist elsewhere along the margin where the majority of relief may be a relict relating to processes associated with Cretaceous rifting (e.g. Seidl et al., 1996).

\section{Conclusions}

A multidisciplinary investigation of Mountain Lagoon confirms that the origin of the basin can be linked to tectonic uplift on the Kurrajong Fault. Two episodes of neotectonic uplift are recorded on the Kurrajong Fault; the first in the Mio-Pliocene and the second in the Middle Pleistocene at around $200 \mathrm{ka}$, with each generating a similar amount of displacement $(\sim 7-8 \mathrm{~m})$. Our findings indicate that a maximum of only $15 \mathrm{~m}$ of the $130 \mathrm{~m}$ of throw across the Kurrajong Fault is Neogene or younger in age. This relatively small proportion of neotectonic displacement recorded within the LSC suggests that erosional exhumation of pre-existing (Paleogene) structure is the dominant process responsible for the formation of the present relief at the eastern range front of the Blue Mountains Plateau. Estimated rates of tectonic uplift ( $\sim \mathrm{m} / \mathrm{Ma}$ - this study) are an order of magnitude less than calculated long-term denudation rates $(21.5 \pm 7 \mathrm{~m} / \mathrm{Ma}$ - Tomkins et al., 2007), which also implies that tectonism has a relatively limited influence on the geomorphic evolution of the escarpment in this region (e.g. Nott et al., 1996).

A comparison between two physiographically-similar structures within the Australian south-eastern highlands - the LSC and the Lake George Fault - demonstrate that the extent and magnitude of Neogene and younger deformation differs markedly. Accordingly, present-day topography is considered to be a poor proxy for understanding the timing and scale of relief building across faults of the south-eastern highlands. Along with evidence from previous studies (e.g. Singh et al., 1981; Abell, 1985, 1991; Holdgate et al., 2008; Vandenberg, 2010; Holdgate et al., 2011; Webb et al., 2011), the new data from the LSC demonstrate that episodic post-rift faulting deformation is an important driver of uplift and consequent relief generation in the elevated passive margin setting of south-eastern Australia, consistent with observations in similar settings worldwide (e.g. Japsen et al., 2009). The present study also highlights that the relative proportion of rift and post-rift uplift is characterized by high spatial variability.

Acknowledgements - The authors gratefully acknowledge productive discussions with, and field assistance from, Andrew Rawson, Kerrie Tomkins and Alison Kirkby. The authors would also like to thank Kylia Wall and Christian Thun for preparing the organic extracts for palynological analysis, and Judith Shelley for picking the core samples for ostracods. Reviews of a draft manuscript by Lisa Hall and John Wilford improved the document. This paper is published with the permission of the Chief Executive Officer of Geoscience Australia.

\section{References}

Abell RS. 1985. Geology of the Lake George Basin, NSW, Record 1985/ 4. Bureau of Mineral Resources: Canberra.

Abell RS. 1991. Geology of the Canberra 1:100 000 sheet area. Bureau of Mineral Resources, Australia, Bulletin 233: 116.

Adamiec G, Aitken MJ. 1998. Dose-rate conversion factors: update. Ancient TL 16: 37-50.

Adamson CL. 1962. The Green Scrub basalt deposit near Mountain Lagoon. New South Wales Geological Survey Report 12: 1-2.

Andrews EC. 1910. Geographical unity of eastern Australia in late and post Tertiary time with applications to biological problems. Journal and Proceedings of the Royal Society of New South Wales 44: 420-480.

Beavis F. 1960. The Tawonga Fault, northeast Victoria. Proceedings of the Royal Society of Victoria 72: 95-100.

Beavis F. 1962. The geology of the Kiewa area. Proceedings of the Royal Society of Victoria 75: 349-410.

Beavis FC, Beavis JC. 1976. Structural geology in the Kiewa region of the Metamorphic Complex, North-East Victoria. Proceedings of the Royal Society of Victoria 88: 66-75.

Bishop P. 1985. Southeast Australian late Mesozoic and Cenozoic denudation rates: a test for late Tertiary increases in continental denudation. Geology 13: 479-482.

Bishop P. 1986. Horizontal stability of the Australian continental drainage divide in south central New South Wales during the Cainozoic. Australian Journal of Earth Sciences 33: 295-307. DOI: 10.1080/ 08120098608729367

Bishop P, Goldrick G. 2000. Geomorphological evolution of the East Australian continental margin. In Geomorphology and Global Tectonics, Summerfield MA (ed). John Wiley \& Sons: Chichester; 227-255.

Bishop P, Hunt P, Schmidt PW. 1982. Limits to the age of the Lapstone Monocline, NSW; a paleomagnetic study. Journal of the Geological Society of Australia 29: 319-326. DOI: 10.1080/00167618208729216

Bishop P, Hunter T. 1990. Pebble Fabrics in the Rickabys Creek Gravel and their Implications for the Relationships between the Lapstone Monocline and the Rickabys Creek Gravel, New South Wales Geological Survey Report 1990/281. Geological Survey of New South Wales: Maitland.

Bishop P, Young RW, McDougall I. 1985. Stream profile change and long term landscape evolution; early Miocene and modern rivers of the East Australian highland crest, central New South Wales, Australia. Journal of Geology 93: 455-474.

Black MP, Mooney SD, Haberle SG. 2007. The fire, human and climate nexus in the Sydney Basin, eastern Australia. The Holocene 17: 465-478.

Bonow JM, Lidmar-Bergstrom K, Japsen P. 2006. Palaeosurfaces in central West Greenland as reference for identification of tectonic movements and estimation of erosion. Global and Planetary Change 50: $161-183$. 
Branagan DF. 1975. Further thoughts on the Lapstone Structure. In Proceedings of the 10th symposium on Advances in the Study of the Sydney Basin, Engel BA (ed). Department of Geology, University of Newcastle: Newcastle; 22-23.

Branagan DF, Pedram H. 1990. The Lapstone Structural Complex, New South Wales. Australian Journal of Earth Sciences 37: 23-36. DOI: 10.1080/08120099008727902

Braun J, Burbidge DR, Gesto FN, Sandiford M, Gleadow AJW, Kohn BP, Cummins PR. 2009. Constraints on the current rate of deformation and surface uplift of the Australian continent from a new seismic database and low-T thermochronological data. Australian Journal of Earth Sciences 56: 99-110.

Bray A, Hatherly P, Fergusson CL. 2010. Seismic reflection evidence for the evolution of the Camden Syncline and Lapstone Structural Complex, central Sydney Basin, Australia. Australian Journal of Earth Sciences 57: 993-1004. DOl: 10.1080/08120099.2010.509406

Brown MC. 2008. Discussion and reply - no mountains to snow on: major post-Eocene uplift of the East Victoria Highlands; evidence from Cenozoic deposits. Australian Journal of Earth Sciences 55: 1181-1187.

Browne WR. 1967. Geomorphology of the Kosciusko block and its north and south extensions. Proceedings of the Linnean Society of New South Wales 92: 117-144.

Bryan JH. 1966. Sydney 1:250 000 Geological Sheet SI/56-05, 3rd edn. Geological Survey of New South Wales: Sydney.

Chesnut WS. 1982. Notes on the Occurrence of Lateritic Gravels (?Rickabys Creek Gravel) at the RAAF Base, Lapstone, NSW, New South Wales Geological Survey Report 1980/473. Geological Survey of New South Wales: Maitland

Clark D, McPherson A, Van Dissen R. 2012. Long-term behaviour of Australian Stable Continental Region (SCR) faults. Tectonophysics 566-567: 1-30. DOI: 10.1016/j.tecto.2012.07.004

Clark D, Rawson A. 2009. New field observations pertaining to the age and structure of the northern Lapstone Structural Complex, and implications for seismic hazard. In Potential Geologic Sources of Seismic Hazard in the Sydney Basin - Proceedings Volume of a One Day Workshop, April 2005, Clark D (ed). Geoscience Australia Record 2009/011. Geoscience Australia: Canberra; 31-45.

Coventry RJ. 1976. Abandoned shorelines and the late Quaternary history of Lake George, New South Wales. Journal of the Geological Society of Australia 23: 249-273.

Crook KAW. 1956. The Geology of the Kurrajong-Grose River District, MSc Thesis. University of Sydney (unpublished).

Czarnota K, Hoggard MJ, White N, Winterbourne J. 2013. Spatial and temporal patterns of Cenozoic dynamic topography from around Australia. Geochemistry, Geophysics, Geosystems 14: 634-658. DOI: 10.1029/2012GC004392

Czarnota K, Roberts GG, White N, Fishwick S. 2014. Spatial and temporal pattern of Australian dynamic topography from river profile modeling. Journal of Geophysical Research - Solid Earth. DOI: 10.1029/2013JB010436

David TWE. 1896. The structure and origins of the Blue Mountains. Journal and Proceedings of the Royal Society of New South Wales 30: 33-69.

David TWE. 1902. An important geological fault at Kurrajong, NSW. Journal and Proceedings of the Royal Society of New South Wales 36: 359-370.

Dickinson JA, Wallace MW, Holdgate GR, Daniels J, Gallagher SJ, Thomas L. 2001. Neogene tectonics in SE Australia: implications for petroleum systems. Australian Petroleum Production and Exploration Association Journal 41: 37-52.

Dickinson JA, Wallace MW, Holdgate GR, Gallagher SJ, Thomas L. 2002. Origin and timing of the Miocene-Pliocene unconformity in southeast Australia. Journal of Sedimentary Research 72: 288-303. DOI: 10.1306/082701720288

Dyksterhuis S, Müller RD. 2008. Cause and evolution of intraplate orogeny in Australia. Geology 36: 495-498. DOI: 10.1130/G24536A.1

Fergusson CL, Bray A, Hatherly P. 2011. Cenozoic development of the Lapstone Structural Complex, Sydney Basin, New South Wales. Australian Journal of Earth Sciences 58: 49-59. DOI: 10.1080/ 08120099.2011.534505

Fitzsimmons KE, Barrows TT. 2010. Holocene hydrologic variability in temperate southeastern Australia: an example from Lake George, New South Wales. The Holocene 20: 1-13.
Galbraith RF, Roberts RG, Laslett GM, Yoshida H, Olley JM. 1999. Optical dating of single and multiple grains of quartz from Jinmium rock shelter, northern Australia: part I. Experimental design and statistical models. Archaeometry 41: 339-364.

Gallagher K, Brown R. 1999a. Denudation and uplift at passive margins: the record on the Atlantic Margin of Southern Africa. Philosophical Transactions of the Royal Society of London 357: 835-859.

Gallagher K, Brown R. 1999b. The Mesozoic denudation history of the Atlantic margins of southern Africa and southeast Brazil and the relationship to offshore sedimentation. In The Oil and Gas Habitats of the South Atlantic, Cameron NR, Bate RH, Clure VS (eds). Geological Society Special Publication 153. Geological Society: London; 41-53.

Galloway MC. 1967. The stratigraphy of the Putty-Upper Colo area, Sydney Basin, NSW. Journal and Proceedings of the Royal Society of New South Wales 101: 23-36.

Gobert V. 1978. Proposed nomenclature for the Cainozoic sediments of the Penrith-Windsor area. New South Wales Geological Survey Quarterly Notes 32: 1-9.

Grady A, Hogbin H. 1926. Mountain Lagoon and the Kurrajong Fault. Journal and Proceedings of the Royal Society of New South Wales 60: $119-129$.

Griffiths DH, Turnbull J. 1985. A multi-electrode array for resistivity surveying. First Break 3: 16-20. DOI: 10.3997/1365-2397.1985013

Griffiths DH, Turnbull J, Olayinka AI. 1990. Two-dimensional resistivity mapping with a computer-controlled array. First Break 8: 121-129. DOI: 10.3997/1365-2397.1990008

Harrington HJ, Korsch RJ. 1985. Tectonic model for the Devonian to middle Permian of the New England Orogen. Australian Journal of Earth Sciences 32: 163-179. DOI: 10.1080/08120098508729322

Heimsath AM, Chappell BW, Fifield K. 2010. Eroding Australia: rates and processes from Bega Valley to Arnhem Land. In Australian Landscapes, Bishop P, Pillans B (eds). Geological Society, London, Special Publication 346. Geological Society: London; 225-242.

Heimsath AM, Chappell J, Dietrich WE, Nishiizumi K, Finkel RC. 2000. Soil production on a retreating escarpment in southeastern Australia. Geology 28: 787-790.

Heimsath AM, Chappell J, Dietrich WE, Nishiizumi K, Finkel RC. 2001. Late Quaternary erosion in southeastern Australia: a field example using cosmogenic isotopes. Quaternary International 83-85: 169-185. DOI: 10.1016/S1040-6182(01)00038-6

Heine C, Muller RD, Steinberger B, DiCaprio L. 2010. Integrating deep Earth dynamics in paleogeographic reconstructions of Australia. Tectonophysics 483: 135-150. DOI: 10.1016/j.tecto.2009.08.028

Henderson P. 1975. The Geomorphology of Mountain Lagoon, BSc Thesis. University of Sydney (unpublished).

Henry HM. 1987. Mellong Plateau, central eastern New South Wales: an anomalous landform. Journal and Proceedings of the Royal Society of New South Wales 120: 117-134.

Herbert C. 1979. The Geology and Resource Potential of the Wianamatta Group, New South Wales Geological Survey Bulletin 25. Geological Survey of New South Wales: Maitland.

Herbert C. 1989. The Lapstone Monocline - Nepean Fault; a high angle reverse fault system. In Proceedings of the 23rd symposium on Advances in the Study of the Sydney Basin, Boyd RL, Allen K (eds). Department of Geology, University of Newcastle: Newcastle; $217-224$

Herbert C, Helby R. 1980. A Guide to the Sydney Basin, New South Wales Geological Survey Bulletin 26. Geological Survey of New South Wales: Maitland.

Hillis RR, Sandiford M, Reynolds SD, Quigley MC. 2008. Present-day stresses, seismicity and Neogene-to-Recent tectonics of Australia's 'passive' margins: intraplate deformation controlled by plate boundary forces. In The Nature and Origin of Compression in Passive Margins, Johnson $H$, Doré AG, Gatliff RW, Holdsworth R, Lundin ER, Ritchie JD (eds). Geological Society, London, Special Publication 306. Geological Society: London; 71-90.

Holdgate GR, Wallace MW, Gallagher SJ, Witten RB, Stats B, Wagstaff BE. 2006. Cenozoic fault control on 'deep lead' palaeoriver systems, Central Highlands, Victoria. Australian Journal of Earth Sciences 53: 445-468. DOI: 10.1080/08120090600632334

Holdgate GR, Wallace MW, Gallagher SJ, Wagstaff BE, Moore D. 2008. No mountains to snow on: major post-Eocene uplift of the 
East Victoria Highlands; evidence from Cenozoic deposits. Australian Journal of Earth Sciences 55: 211-234. DOI: 10.1080/ 08120090701689373

Holdgate GR, Wallace MW, Gallagher SJ, Wagstaff BE, Moore D. 2011. Paleogene basalts prove early uplift of Victoria's Eastern Uplands. Australian Journal of Earth Sciences 58: 95-99. DOI: 10.1080/ 08120099.2011.535016

Holford S, Tassone D, King R, Hillis R. 2012. Neotectonics and stress in southeastern Australia over Cenozoic to contemporary timescales. In Proceedings of the 34th International Geological Congress, 5-10 August 2012, Brisbane, Australia.

Institute of Geological and Nuclear Sciences (IGNS). 1999. Seismic Hazard Analysis, Lucas Heights; Site of the High Flux Australian Reactor, ANSTO Report, December 1999. Institute of Geological and Nuclear Sciences/Australian Department of Industry, Science and Resources: Lower Hutt.

Jamison WR. 1987. Geometric analysis of fold development in overthrust terranes. Journal of Structural Geology 9: 207-220.

Japsen P, Bonow JM, Green PF, Chalmers JA, Lidmar-Bergstrom K. 2006. Elevated, passive continental margins: Long-term highs or Neogene uplifts? New evidence from West Greenland. Earth and Planetary Science Letters 248: 330-339. DOI: 10.1016/j.epsl.2006.05.036

Japsen P, Bonow JM, Green PF, Chalmers JA, Lidmar-Bergstrom K. 2009. Formation, uplift and dissection of planation surfaces at passive continental margins - a new approach. Earth Surface Processes and Landforms 34: 683-699. DOI: 10.1002/esp.1766

Kirkby AL, Clark D, McPherson A. 2009. Drainage Modification Associated with the Northern Lapstone Structural Complex, New South Wales, Australia, Geoscience Australia Record 2009/06. Geoscience Australia: Canberra.

Kohn BP, Gleadow AJW, Cox SJD. 1999. Denudation history of the Snowy Mountains: constraints from apatite fission track thermochronology. Australian Journal of Earth Sciences 46: 181-198. DOI: 10.1046/ j.1440-0952.1999.00703.x

Lambert IB, White AIR. 1965. The Berridale Wrench fault: a major structure in the Snowy Mountains of New South Wales. Australian Journal of Earth Sciences 12: 25-33. DOI: 10.1080/00167616508728583

Leaman DE. 1990. Geological note: the Sydney Basin: composition of basement. Australian Journal of Earth Sciences 37: 107-108. DOI: 10.1080/08120099008727910

Macphail MK. 1997. Late Neogene climates in Australia: fossil pollenand spore-based estimates in retrospect and prospect. Australian Journal of Botany 45: 425-464.

Macphail MK. 1999. Palynostratigraphy of the Murray Basin, inland southeastern Australia. Palynology 23: 199-242.

Macphail MK. 2013. Neotectonism in the Sydney Basin: Revision of Palynostratigraphic Evidence from Mountain Lagoon, Palynostratigraphic report prepared for the Natural Hazards Impacts Project Group, Geoscience Australia (4 March 2013). Consultant Palynological Services: Canberra (unpublished).

McBride JH, Nelson WJ. 1999. Style and origin of mid-Carboniferous deformation in the Illinois Basin, USA - Ancestral Rockies deformation? Tectonophysics 305: 249-273. DOI: 10.1016/S0040-1951(99)00015-3

Mauger AJ, Creasey JW, Huntingdon JF. 1984. The Use of Predevelopment Data for Mine Design: Sydney Basin Fracture Pattern Analysis, National Energy Research Development and Demonstration Council Report No. 0343, July 1984. National Energy Research Development and Demonstration Council: Canberra.

McPherson A, Clark D, Cupper M, Collins CDN, Nelson G. 2012. The Cadell Fault: a record of long-term fault behaviour in south-eastern Australia. In Proceedings of the $2^{\text {nd }}$ Australian Regolith Geoscientists Association Conference $/ 22^{\text {nd }}$ Australian Clay Minerals Society Conference, 7-9 February 2012, Mildura, Victoria; 7-16.

Moye DG, Sharp KR, Stapledon DH. 1963. Geology of the Snowy Mountains Region. Snowy Mountains Hydro-electric Authority, Cooma (unpublished - held in Geological Survey of New South Wales Library).

Murray-Wallace CV. 2002. Pleistocene coastal stratigraphy, sea-level highstands and neotectonism of the southern Australian passive continental margin - a review. Journal of Quaternary Science 17: 469-489. DOI: $10.1002 / j q s .717$

Nanson GC, Young RW. 1987. Comparison of thermoluminescence and radiocarbon age-determinations from Late-Pleistocene alluvial deposits near Sydney, Australia. Quaternary Research 27: 263-269.
Nott JF, Young RW, McDougall I. 1996. Wearing down, wearing back and gorge extension in the long term evolution of a highland mass: quantitative evidence from the Shoalhaven catchment, southeast Australia. Journal of Geology 104: 224-232.

Norvick MS. 2011. Paleogene basalts prove early uplift of Victoria's Eastern Uplands. Australian Journal of Earth Sciences 58: 93-94. DOI: 10.1080/08120099.2011.535015

Norvick MS, Smith MA. 2001. Mapping the plate tectonic reconstruction of southern and southeastern Australia and implications for petroleum systems. Australian Petroleum Production and Exploration Association Journal 41: 15-35.

Orr ML. 1999. Tectonic Geomorphology of the Bogong and Dargo High Plains Region, East Victorian Highlands, Australia, PhD Thesis. University of Melbourne (unpublished).

O'Sullivan PB, Orr M, O'Sullivan AJ, Gleadow AJW. 1999. Episodic Late Paleozoic to Cenozoic denudation of the southeastern highlands of Australia: evidence from the Bogong High Plains, Victoria. Australian Journal of Earth Sciences 46: 199-216. DOI: 10.1046/ j.1440-0952.1999.00704.x

Partridge AD. 1999. Late Cretaceous to Tertiary Geological Evolution of the Gippsland Basin, Victoria, PhD Thesis. La Trobe University, Melbourne (unpublished).

Pedram H. 1983. Structure and Engineering Geology of the Lower Blue Mountains, Sydney Basin, NSW, Australia, MSc Thesis. University of Sydney (unpublished).

Pickett JW, Bishop P. 1992. Aspects of landscape evolution in the Lapstone Monocline area, New South Wales. Australian Journal of Earth Sciences 39: 21-28. DOI: 10.1080/08120099208727997

Pillans B. 2003. Dating ferruginous regolith to determine seismic hazard at Lucas Heights, Sydney. In Advances in Regolith, Roach IC (ed). Cooperative Research Centre for Landscape Evolution and Mineral Exploration: Perth; 324-327.

Prescott JR, Hutton JT. 1994. Cosmic ray contributions to dose rates for luminescence and ESR dating: large depths and long-term time variations. Radiation Measurements 23: 497-500.

Quigley M, Clark D, Sandiford M. 2010. Late Cenozoic tectonic geomorphology of Australia, In Australian Landscapes, Bishop P, Pillans B (eds). Geological Society, London, Special Publication 346. Geological Society: London; 243-265.

Quigley MC, Cupper ML, Sandiford M. 2006. Quaternary faults of south-central Australia: paleoseismicity, slip rates and origin. Australian Journal of Earth Sciences 53: 285-301. DOI: 10.1080/ 08120090500499271

Qureshi LR. 1984. Wollondilly-Blue Mountains gravity gradient and its bearing on the origin of the Sydney Basin. Australian Journal of Earth Sciences 31: 293-302. DOI: 10.1080/14400958408527932

Rawson A, Clark D. 2009. Geomorphological evidence for Neotectonic activity on the northern Lapstone Structural Complex. In Potential Geologic Sources of Seismic Hazard in the Sydney Basin - Proceedings Volume of a One Day Workshop, April 2005, Clark D (ed). Geoscience Australia Record 2009/011. Geoscience Australia: Canberra; $19-30$.

Rawson GA. 1990. Drainage Modification Associated with the Lapstone Structural Complex, New South Wales: Geomorphological Evidence for Neotectonism, MSc Thesis. University of Sydney (unpublished).

Riley SJ, Henry HM. 1987. A geophysical survey of Culloul and Mellong Creek Valley fills: implications for valley development in sandstone terrain. Journal and Proceedings of the Royal Society of New South Wales 120: 101-115.

Robbie A, Martin HA. 2007. The history of the vegetation from the Last Glacial Maximum at Mountain Lagoon, Blue Mountains, New South Wales. Proceedings of the Linnean Society of New South Wales 128: 57-80.

Rose G. 1966. Wollongong 1:250 000 Geological Sheet SI/56-09, 2nd edn. Geological Survey of New South Wales: Sydney.

Sandiford M, Wallace M, Coblentz D. 2004. Origin of the in situ stress field in southeastern Australia. Basin Research 16: 325-338. DOI: 10.1111/j.1365-2117.2004.00235.x

Schmidt PW, Lackie MA, Anderson JC. 1995. Paleomagnetic evidence for the age of the Lapstone Monocline, NSW. Australian Coal Geology 10: 14-18.

Seidl MA, Weissel JK, Pratson LF. 1996. The kinematics and pattern of escarpment retreat across the rifted continental margin of SE 
Australia. Basin Research 12: 301-316. DOI: 10.1046/j.13652117.1996.00266.x

Sharp KR. 2004. Cenozoic volcanism, tectonism and stream derangement in the Snowy Mountains and northern Monaro of New South Wales. Australian Journal of Earth Sciences 51: 67-83. DOI: 10.1046/j.1400-0952.2003.01045.x

Singh G, Opdyke ND, Bowler JM. 1981. Late Cainozoic stratigraphy, magnetic chronology and vegetational history from Lake George, NSW. Journal of the Geological Society of Australia 28: 435-452. DOI: 10.1080/00167618108729180

Sniderman JMK, Pillans B, O'Sullivan PB, Kershaw AP. 2007. Climate and vegetation in southeastern Australia respond to Southern Hemisphere insolation forcing in the late Pliocene-early Pleistocene. Geology 35: 41-44. DOI: 10.1130/G23247A.1

Sprigg RC. 1945. Some aspects of the geomorphological of portion of the Mount Lofty Ranges. Transactions of the Royal Society of South Australia 69: 277-304.

Suppe J, Medwedeff DA. 1984. Fault-propagation folding. Geological Society of America, Abstracts 16: 670.

Tindall SE, Davis GH. 1999. Monocline development by oblique-slip fault-propagation folding: the East Kaibab monocline, Colorado Plateau, Utah. Journal of Structural Geology 21: 1303-1320.

Tomkins KM, Humphreys GS, Wilkinson MT, Fink D, Hesse PP, Doerr SH, Shakesby RA, Wallbrink PJ, Blake WH. 2007. Contemporary versus long-term denudation along a passive plate margin: the role of extreme events. Earth Surface Processes and Landforms 32: 1013-1031. DOI: 10.1002/esp.1460

Vandenberg AHM. 2010. Paleogene basalts prove early uplift of Victoria's Eastern Uplands. Australian Journal of Earth Sciences 57: 291-315. DOI: 10.1080/08120091003619225

van der Beek PA, Braun J. 1999. Controls on post-mid-Cretaceous landscape evolution in the southeastern highlands of Australia: insights from numerical surface process models. Journal of Geophysical Research 104: 4945-4966. DOI: 10.1029/1998JB900060

van der Beek PA, Braun J, Lambeck K. 1999. Post-Palaeozoic uplift history of southeastern Australia revisited: results from a process-based model of landscape evolution. Australian Journal of Earth Sciences 46: 157-172. DOl: 10.1046/j.1440-0952.1999.00701.x van der Beek P, Pulford A, Braun J. 2001. Cenozoic Landscape Development in the Blue Mountains (SE Australia): lithological and tectonic controls on rifted margin morphology. Journal of Geology 109: 35-56.

Webb JA, Gardner TW, Kapostasy D, Bremar KA, Fabel D. 2011 Mountain building along a passive margin: Late Neogene tectonism in southeastern Victoria, Australia. Geomorphology 125: 253-262. DOI: 10.1016/j.geomorph.2010.09.022

Weissel JK, Karner GD. 1989. Flexural uplift of rift flanks due to mechanical unloading of lithosphere during extension. Journal of Geophysical Research 94: 13919-13950.

Weissel JK, Seidl MA. 1998. Inland propagation of erosional escarpments and river profile evolution across the southeast Australian passive continental margin. In Rivers Over Rock: Fluvial Processes in Bedrock Channels, Tinkler KJ, Wohl EE (eds). Geophysical Monograph Series, Vol. 107. American Geophysical Union: Washington, DC; 189-206.

Wellman P. 1987. Eastern highlands of Australia; their uplift and erosion. Bureau of Mineral Resources. Journal of Australian Geology and Geophysics 10: 277-286.

Wellman P, McDougall I. 1974. Potassium-argon ages on the Cainozoic volcanic rocks of New South Wales. Journal of the Geological Society of Australia 21 : 247-272.

Wilkinson MT, Chappell J, Humphreys GS, Fifield K, Smith B, Hesse P. 2005. Soil production in heath and forest, Blue Mountains, Australia: influence of lithology and paleoclimate. Earth Surface Processes and Landforms 30: 923-934. DOI: 10.1002/esp.1254

Young RW. 1981. Denudational history of the south-central uplands of New South Wales. Australian Geographer 15: 77-88.

Young RW, Bishop P. 1980. Potassium-argon ages on Cainozoic volcanic rocks in the Crookwell-Goulburn area, New South Wales. Search 11: 340-341.

\section{SUPPORTING INFORMATION}

Additional supporting information may be found in the online version of this article at the publisher's web site. 